\title{
WestVirginiaUniversity
}

THE RESEARCH REPOSITORY @ WVU

Graduate Theses, Dissertations, and Problem Reports

2013

\section{Geochemistry of mine pool discharges in the Pittsburgh coal basin}

Timothy A. Denicola

West Virginia University

Follow this and additional works at: https://researchrepository.wvu.edu/etd

\section{Recommended Citation}

Denicola, Timothy A., "Geochemistry of mine pool discharges in the Pittsburgh coal basin" (2013).

Graduate Theses, Dissertations, and Problem Reports. 4960.

https://researchrepository.wvu.edu/etd/4960

This Thesis is protected by copyright and/or related rights. It has been brought to you by the The Research Repository @ WVU with permission from the rights-holder(s). You are free to use this Thesis in any way that is permitted by the copyright and related rights legislation that applies to your use. For other uses you must obtain permission from the rights-holder(s) directly, unless additional rights are indicated by a Creative Commons license in the record and/ or on the work itself. This Thesis has been accepted for inclusion in WVU Graduate Theses, Dissertations, and Problem Reports collection by an authorized administrator of The Research Repository @ WVU. For more information, please contact researchrepository@mail.wvu.edu. 


\title{
GEOCHEMISTRY OF MINE POOL DISCHARGES IN THE PITTSBURGH COAL BASIN
}

\author{
Timothy A. Denicola
}

Thesis Submitted to:

The Eberly College of Arts and Sciences at West Virginia University in partial fulfillment of the requirements for the degree of

\author{
Masters of Science \\ In \\ Geology \\ Dr. Joseph J. Donovan, Chair \\ Bruce R. Leavitt, PE, PG \\ Dr. Shikha Sharma, Ph.D.
}

Morgantown, WV

2013

Department of Geology and Geography

Keywords: Pittsburgh coal, mine discharges, geochemistry, hydrology, principal component analysis, cluster analysis 


\section{ABSTRACT \\ GEOCHEMISTRY OF MINE POOL DISCHARGES \\ IN THE PITTSBURGH COAL BASIN}

\section{Timothy A. Denicola}

Seventy-two mine water discharges from flooded underground mines of the Pittsburgh coal bed were sampled for chemistry during 2012. Statistical techniques including correlation, principal component analysis (PCA), and cluster analysis (CA) were utilized to evaluate geochemical relationships.

The distributions of most solute concentrations are non-parametric. Strong correlations were observed between constituents of pyrite and carbonate dissolution ( $\left.\mathrm{Fe}, \mathrm{SO}_{4}, \mathrm{Ca}, \mathrm{Mg}\right)$ as well as $\mathrm{Na}$, Sr, and K. Several waters with high scores on PC1 are moderately saline with average concentrations of $\mathrm{Na}(1199 \mathrm{mg} / \mathrm{L}), \mathrm{Cl}(350 \mathrm{mg} / \mathrm{L}), \mathrm{Br}(1.69 \mathrm{mg} / \mathrm{L})$, and $\mathrm{Sr}(4.13 \mathrm{mg} / \mathrm{L})$. Waters with highly negative scores on PC2 are acidic with maximum concentrations of $\mathrm{Fe}^{3+}$ $(35.3 \mathrm{mg} / \mathrm{L})$ and $\mathrm{Al}(23.3 \mathrm{mg} / \mathrm{L})$ and discharge from shallow mines along the eastern margin of the coal subcrop. Waters with highly positive scores on PC2 are alkaline waters from deep, fully flooded mines with $\mathrm{pH}(6.3)$ and alkalinity $(876 \mathrm{mg} / \mathrm{L})$. PC3 has high scores primarily due to elevated Ba.

Pittsburgh coal bed waters display, on average, $\mathrm{SO}_{4}(923 \mathrm{mg} / \mathrm{L}), \mathrm{Na}(267 \mathrm{mg} / \mathrm{L})$, alkalinity (226 mg/L as $\left.\mathrm{CaCO}_{3}\right), \mathrm{Ca}(245 \mathrm{mg} / \mathrm{L}), \mathrm{Cl}(100 \mathrm{mg} / \mathrm{L})$, and $\mathrm{Fe}(45 \mathrm{mg} / \mathrm{L})$ with traces of brine constituents. Diagnostic variations in concentrations of $\mathrm{Ba}, \mathrm{Br}, \mathrm{Sr}, \mathrm{Cl}$, and $\mathrm{Al}$ reveal spatial trends and partitioning into six clusters. 


\section{ACKNOWLEDGMENTS}

I would like to extend my appreciation to Dr. Joseph Donovan for his support and contributions to completion of the thesis. Thanks to Dr. Shikha Sharma and Bruce Leavitt for participating as members of my Master's Committee. Thanks to the WVU Department of Geology Faculty members for providing the knowledge and opportunities that have defined my time here and expanded my comprehension of a fascinating discipline. I offer a final thanks to my friends and loved ones for their unwavering encouragement through the entirety of this experience.

Support is acknowledged from a grant to the WV Water Research Institute from the National Technology Transfer Center. 


\section{TABLE OF CONTENTS}

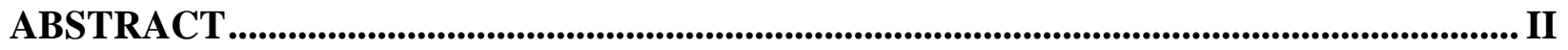

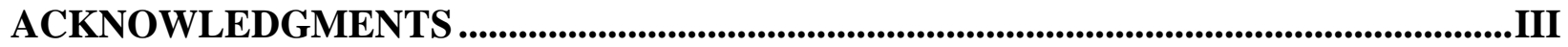

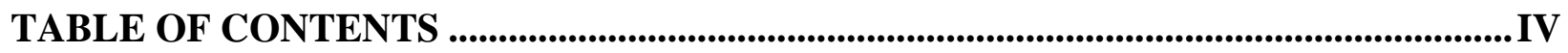

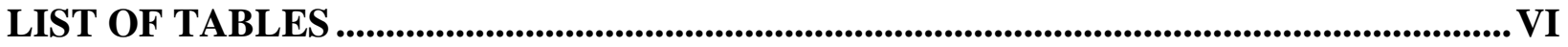

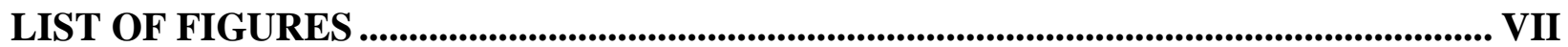

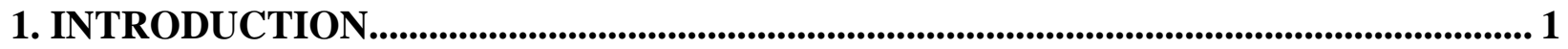

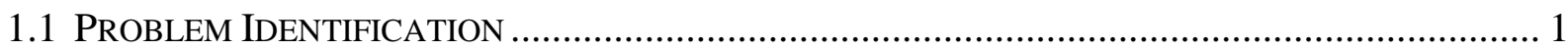

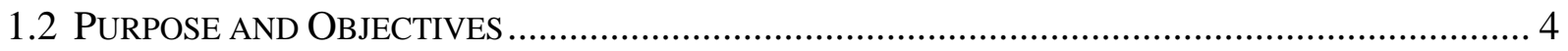

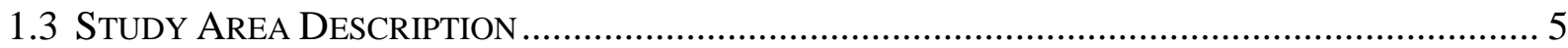

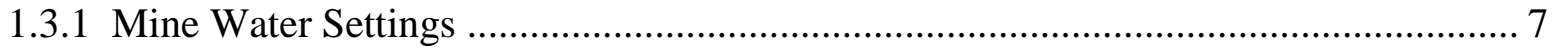

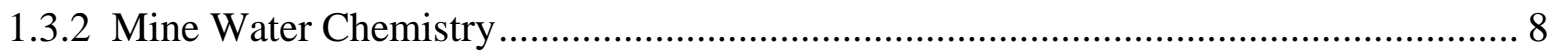

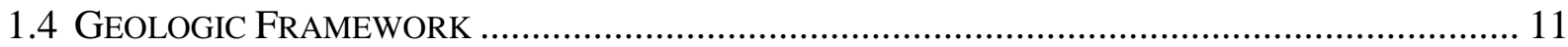

2. METHODOLOGY ............................................................................................................................... 13

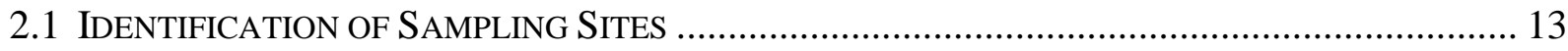

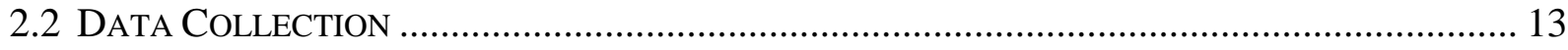

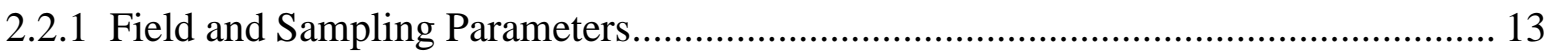

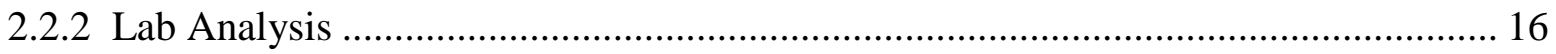

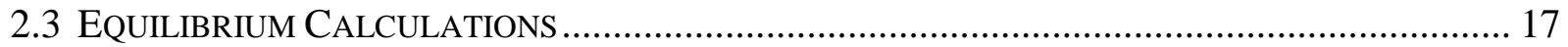

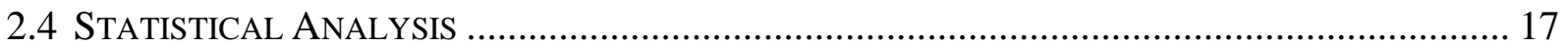




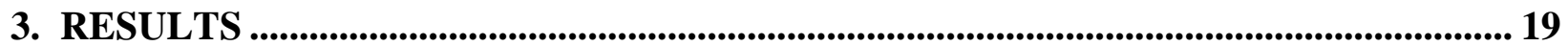

3.1 COMPILATION AND SPECIATION OF CHEMICAL CONSTITUENTS ...................................... 19

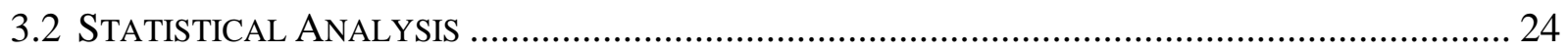

3.2.1 Constituent Distributions ........................................................................... 24

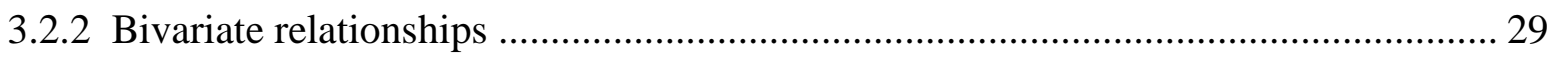

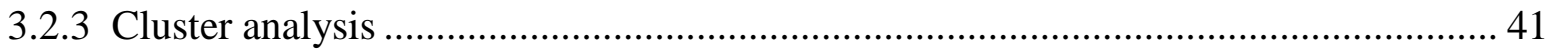

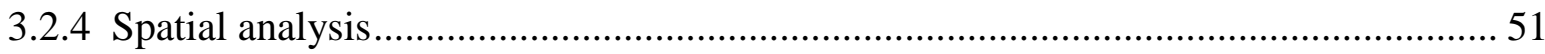

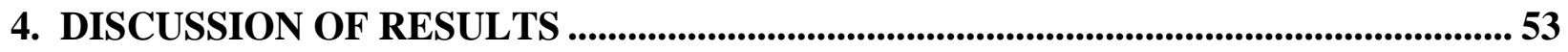

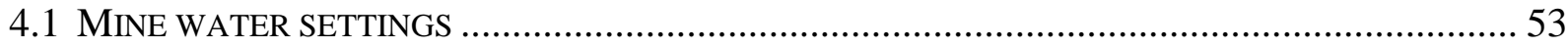

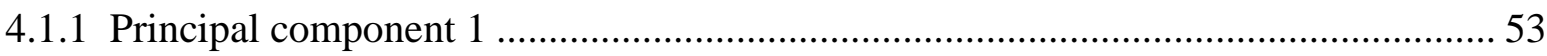

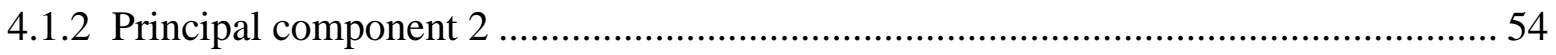

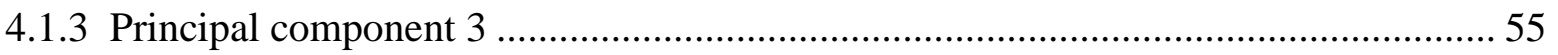

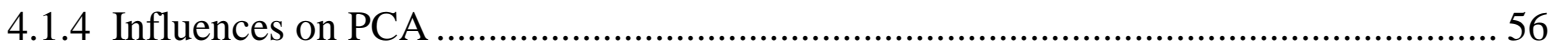

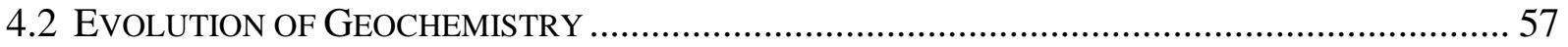

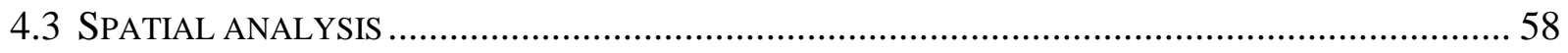

5. CONCLUSIONS ............................................................................................................................. 63

REFERENCES CITED ............................................................................................................ 65 


\section{LIST OF TABLES}

Table 1: Instrumentation and equipment employed for collection of field data.

Table 2: Sample site nomenclature and quality control analytical data. 'ID' represents the sample which originated from a 'minename' and has an abbreviated 'shortID.' Sampling date refers to field collection date; CBE is analytical charge balance error. 'Re-run' indicates re-run samples and the parameters re-run.

Table 3: Raw lab data indicating values below the analytical minimum detection limit. Data is reported as $\mathrm{mg} / \mathrm{L}$

Table 4: Calculated alkalinity for acidic sites $(\mathrm{pH}<4.5)$ based on bicarbonate concentrations interpolated from the $\mathrm{pH}$ vs. activity plot.

Table 5: PHREEQC input file for alkaline and acidic samples. $\mathrm{pCO}_{2}$ for acidic samples was calculated by Henry's Law.

Table 6: Results of Pearson's product moment correlation. 32

Table 7: Principal component scores for each sample on PC1, PC2, and PC3.

Table 8: Cluster averages. $\mathrm{pH}$ is stated as standard units, specific conductance as $\mu \mathrm{S} / \mathrm{cm}$, alkalinity as $\mathrm{mg} / \mathrm{L}$ as $\mathrm{CaCO}_{3}$, and chemical data as $\mathrm{mg} / \mathrm{L}$. 48

Table 9: Mine discharges from target population arranged by results of cluster analysis.

Table 10: Diagnostic properties influencing cluster partitioning. 50 


\section{LIST OF FIGURES}

Figure 1: Subcrop of Pittsburgh coal bed covering Pennsylvania, West Virginia, and Ohio. Shaded region represents known mining in the study area, but does not represent all mining in the Pittsburgh coal bed.

Figure 2: Field sites selected from target population consisting of seventy-one mine discharges and one mine pump.

Figure 3: Annual pumping data from the Clyde mine, Clarksville, PA. ................................ 9

Figure 4: Stratigraphic column of bedrock in the study area. The Pittsburgh coal is immediately overlain by pyritic shale with limestone above (Cecil, 2012) ................................. 12

Figure 5: Plot of $\mathrm{pH}$ vs. activity. Circles represent field alkalinity data from alkaline sites ( $\mathrm{pH}>$ 4.5) plotted against $\mathrm{pH}$. Bicarbonate equilibria under closed system conditions were fitted to the field alkalinity data to interpolate alkalinity for acidic sites $(\mathrm{pH}<4.5) \ldots 23$

Figure 6: Probability density of total ion concentrations, as violin plots (Murrell, 2011). ........ 26

Figure 7: Normality, or lack thereof, of total ion concentrations, as Q-Q plots (Murrell, 2011). 28

Figure 8: Results of Pearson's product moment correlation. Greater elongation and darker shading of the ellipse indicates stronger correlation. Ellipse tilted right indicates positive correlation; ellipse tilted left indicates negative correlation....

Figure 9: Results of Pearson's product moment correlation. Correlations $(r>0.70)$ are shaded.

Figure 10: Scree plot of eigenvalues for principal component analysis (PCA) of mine-water chemistry. Horizontal line $=$ Kaiser cutoff criterion for significant eigenvectors. ..... 33

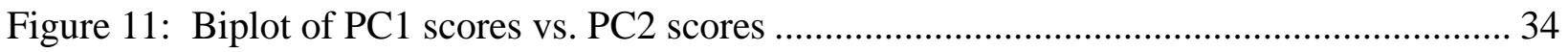

Figure 12: Biplot of PC1 scores vs. PC3 scores. ........................................................... 35

Figure 13: PCA component loadings of standardized chemical data for PC1 vs. PC2 ............. 36

Figure 14: PCA scores of standardized chemical data for PC1 vs. PC2 .................................. 37

Figure 15: PCA component loadings of standardized chemical data for PC1 vs. PC3............. 38

Figure 16: PCA scores of standardized chemical data for PC1 vs. PC3 ................................... 39 
Figure 17: Results of agglomerative hierarchal cluster analysis of standardized chemical data, using Ward's linkage method and Euclidean distance.

Figure 18: Results of cluster analysis presented as standardized chemical data. Horizontal line represents cluster mean for each parameter.

Figure 19: Results of cluster analysis presented as non-standardized chemical data. Horizontal line represents universal mean for each parameter.

Figure 20: Results of cluster analysis presented as non-standardized chemical data. Horizontal line represents universal mean for each parameter. 45

Figure 21: Results of cluster analysis presented as non-standardized chemical data. Horizontal line represents universal mean for each parameter.

Figure 22: Results of cluster analysis presented as biplots of non-standardized data. Selected parameters represent dominant relationships per cluster.

Figure 23: Spatial distribution of cluster analysis results.

Figure 24: Comparison of $\mathrm{pCO}_{2}$ to mine pool depth. $\mathrm{pCO}_{2}$ displayed as log value along y-axis, depth calculation displayed along y-axis, and respective alkaline mine clusters $(\mathrm{C} 1$, C2, C5, C6) along X-axis 


\section{INTRODUCTION}

\subsection{Problem Identification}

Extensive underground mining has taken place in West Virginia and Pennsylvania since the late 1800s, creating local networks of mined voids (West Virginia Geological and Economic Survey, 2007). Infiltration from overlying aquifers, streams, and adjacent flooded mines transmits water into these mines (Perry and Hawkins, 2004). Mined bituminous basins generally develop hydraulically-isolated mine pools, with pressure relief points at individual discharge locations (Capo et al., 2001). Mine discharges in the Pittsburgh coal basin (Figure 1) range from a trickle to 5680 liters per minute; LPM (1500 gallons per minute; gpm). The volume of mine discharge is affected by (a) mine geometry, (b) physical barriers to flow and (c) hydrologic controls. The chemistry of mine discharge is highly dependent on the geometry, amount, and duration of flooding in individual mines (Lambert et al., 2004).

Flooding of underground coal mines creates various safety, environmental, and economic concerns. Coal mine water has the potential to contaminate the regional watershed and damage public and private property. Dissolved metals and other constituents in mine water can be toxic to aquatic organisms and precipitate to form ochreous precipitates that degrade aquatic habitat (Winland et al., 1991; Bigham and Nordstrom, 2000, Cravotta and Kirby, 2004). The burden of remediation of legacy mine sites often falls upon the relevant states and local watershed organizations. Key characteristics of flooded underground coal mine discharges are that:

(a) Flooding develops over years to decades

(b) Geochemistry develops over years to decades

(c) Mine water requires periodic monitoring 


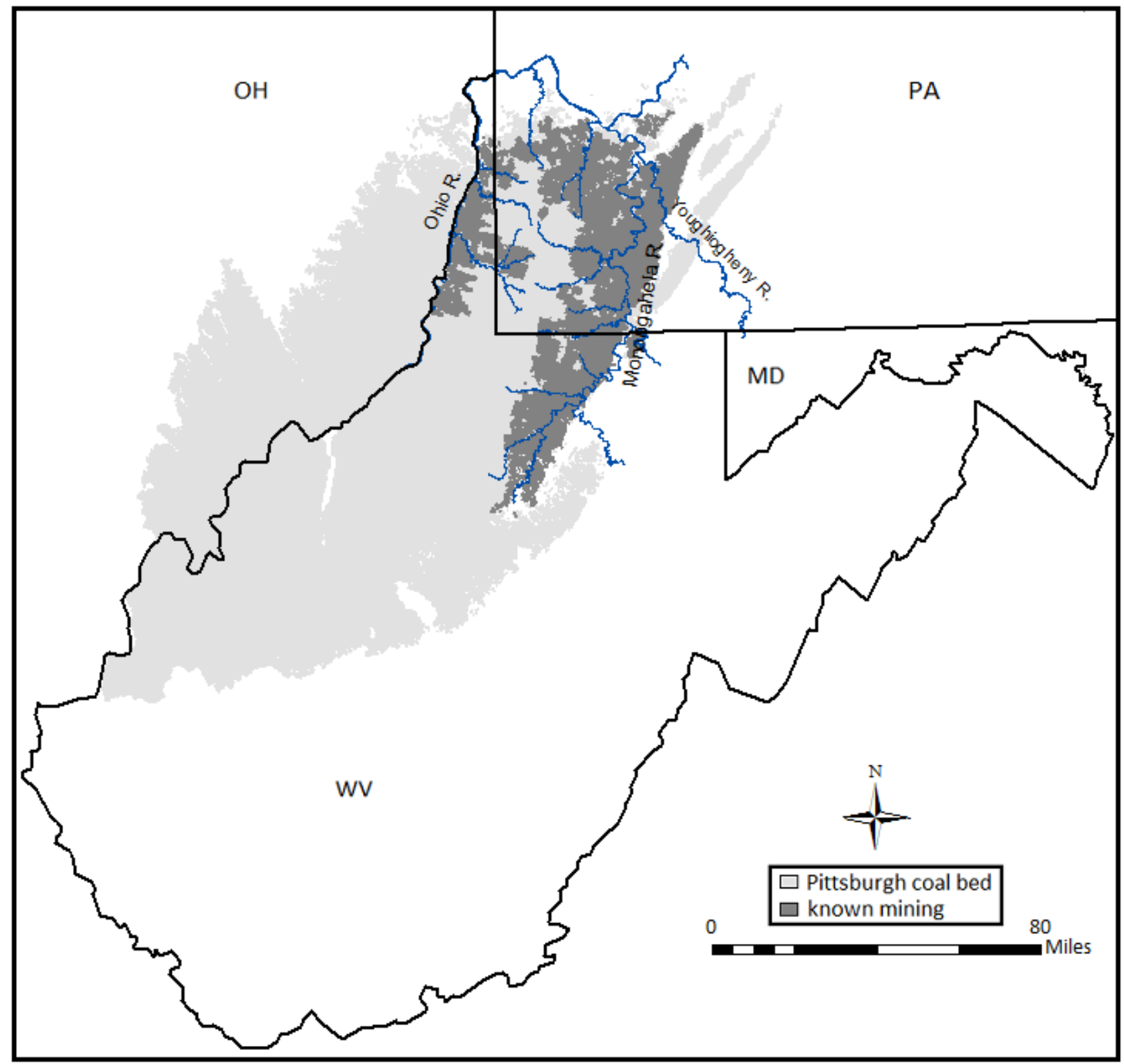

Figure 1: Subcrop of Pittsburgh coal bed covering Pennsylvania, West Virginia, and Ohio. Shaded region represents known mining in the study area, but does not represent all mining in the Pittsburgh coal bed. 
Post-mining hydrology of flooded mines develops over years to decades in response to recharge, discharge, and pumping efforts (or lack thereof) to control hydraulic head. Due to increasing hydraulic head, the Clyde mine treatment plant was expected to increase pumping (Donovan and Leavitt, 2004), but has instead created a surface discharge after failure of the pumps. The uncontrolled increase has resulted in development of a new (2012) discharge into Ten Mile Creek, Washington County, PA. The Isabella mine, Fayette County, PA, displays hydraulic head at topographic elevation indicating a discharge into the Monongahela River has developed. A passive treatment restoration project has been completed on a discharge from the Montour \#4 mine, Washington County, PA. The Eclipse and Vesta mines of Washington County, PA, the Gates and Palmer mines of Fayette County, PA, and several mines of Harrison County, WV, lie within the same region as an increasing density of Marcellus shale gas well drilling. Drilling-related leakage and disposal has the potential to contribute millions of gallons of industrial water to mine aquifer storage.

In unflooded mines, high dissolved oxygen and acidity tend to prevail, forming acidic water generally rich in iron, aluminum, metal cations, and sulfate (Mentz and Wang, 1975; Morris et al., 2008). After mines reach post-mining hydrologic steady-state, their chemistry as well as their water levels tend to stabilize over time (Perry and Hawkins, 2004). Fully-flooded mines of the Pittsburgh coal basin tend to display increased alkalinity, although significant variation in chemistry has been observed. Below-drainage mine water is generally alkaline with iron, but not aluminum, occurring in significant concentrations (McDonough et al., 2005). The development of net-alkaline low-TDS discharges pertains specifically to the Pittsburgh coal basin and some others, but is not representative of all Appalachian coal mines. 
Natural gas extraction in the study area may also influence to geochemistry of Pittsburgh coal mine waters. Mine water is geochemically distinct from Appalachian basin formation water, which is commonly $\mathrm{Na}$ and $\mathrm{Cl}$ dominated with detectable concentrations of barium and bromide (Dresel and Rose, 2010). In addition, elevated concentrations of strontium have been observed in hydrofracking flow-back water (Shramko et al., 2009). The presence of $\mathrm{Na}, \mathrm{Cl}, \mathrm{Ba}$, $\mathrm{Br}$, or $\mathrm{Sr}$ all tends to indicate contributions from either deep-basin formation waters or shallow Pennsylvanian brines emplaced tectonically driven fluid migration (Dresel and Rose, 2010).

\subsection{Purpose and Objectives}

The purpose of this study is to sample and analyze the chemistry of mine water in the Pittsburgh coal basin of the Allegheny plateau (Figure 1). The area was selected because numerous mine water discharges originate from the heavily-mined Pittsburgh coal bed and the region is underlain by flooded, below drainage mine pools. The collected mine water chemical data will be analyzed to determine relationships between chemical and mineralogical constituents, hydrologic conditions, and spatial distribution of mine water geochemistry. Study objectives are:

(a) to identify, sample, and analyze mine waters from various hydrologic settings,

(b) to calculate aqueous speciation and mineral saturation indices, and

(c) to conduct statistical analysis of results.

The target population within the study area will be closed-mine discharges from portals and flowing wells within the Pittsburgh coal basin but will also include one sample taken from a transfer pump moving water from one mine to another. From these, selected field sites will be sampled based upon a set of screening attributes. Donovan and Leavitt (2004) estimated a mined 
area of 0.38 million hectares $(0.94$ million acres $)$ with 0.16 million hectares $(0.39$ million acres $)$ of flooded mine (1.20 billion $\mathrm{m}^{3} ; 42.4$ billion $\mathrm{ft}^{3}$ of water storage) contributing over 325,545 LPM $(86,000 \mathrm{gpm})$ water to the regional watershed. It is estimated that this study will sample about 70 discharges. The principal attribute used to screen sample sites will be magnitude of discharge rate ( $\geq 378.5$ LPM; 100 gpm). Smaller seeps (<378.5 LPM; 100 gpm) exist within the region but are not representative of large volumes of mine water in storage.

Chemical analysis will entail both field and lab analytical techniques. Field analytes will include temperature, $\mathrm{pH}$, specific conductance, dissolved oxygen, oxidation-reduction potential, and alkalinity. Lab analysis will emphasize major ion chemistry and be conducted by the National Research Center for Coal Energy Analytical Laboratory using standard methods and quality control measures.

Relationships and trends in water chemistry will be examined utilizing (a) bivariate correlation , (b) principal component analysis (PCA), and (c) cluster analysis (CA). Speciation and saturation indices will be calculated using PHREEQC (Parkhurst and Appelo, 1999).

\subsection{Study Area Description}

The study area extends 10,356 square kilometers (4,000 square miles) across northern West Virginia and southwestern Pennsylvania within the Allegheny Plateau physiographic province (Fenneman, 1938; Figure 2). The plateau is bound to the east by the Ridge and Valley physiographic province and to the west by the Central Lowlands. The study area lies within the Pittsburgh coal basin, a major portion of the Appalachian coal basin. This large (130 x $65 \mathrm{~km}$; 80 x 40 miles) syncline trends north-northeast in, with coal thickness averaging 1.5 to $2.5 \mathrm{~m}$ thick (5 to $8 \mathrm{ft}$.) (McCoy et al., 2006). Because of its long history, mining techniques employed 


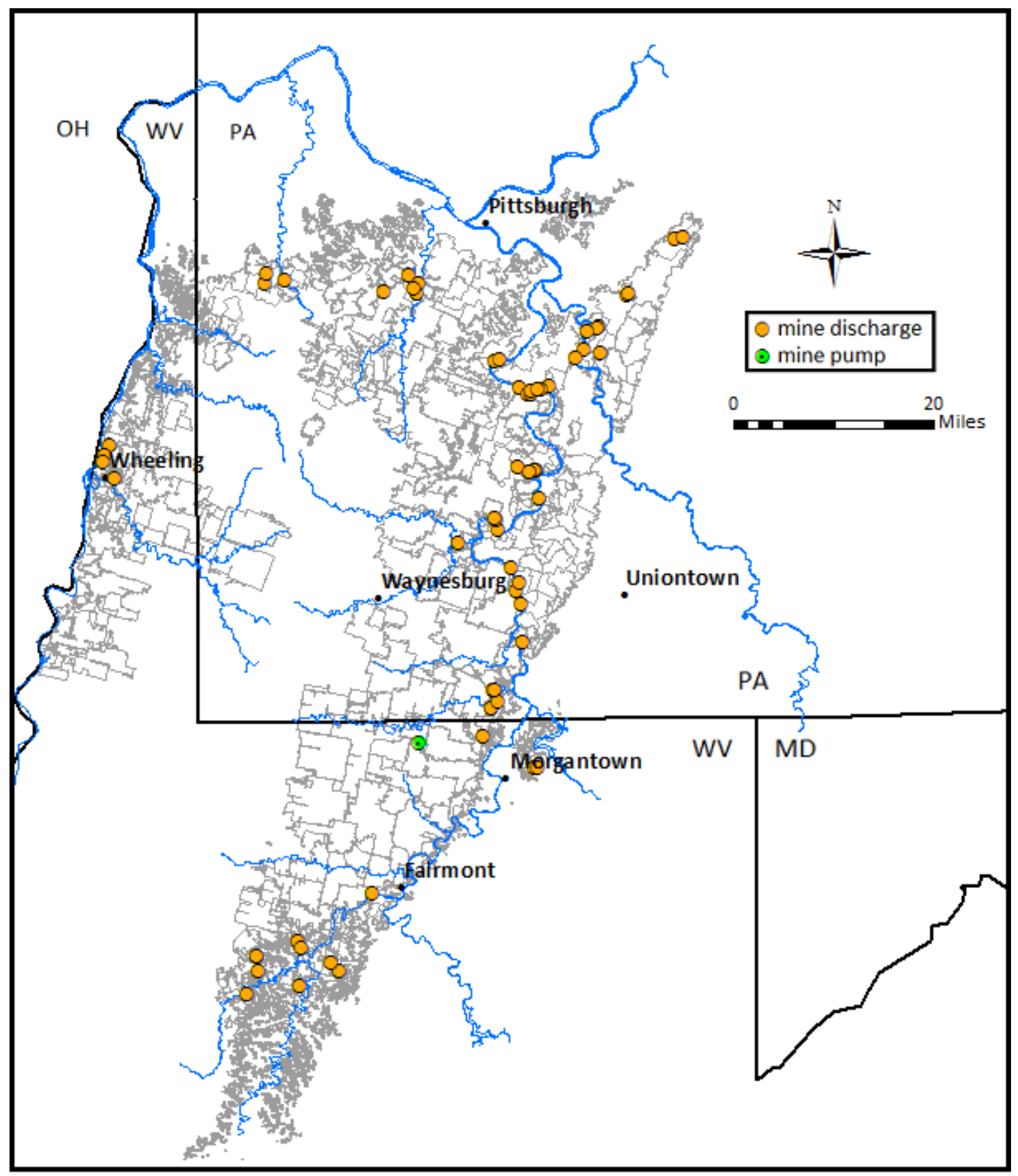

Figure 2: Field sites selected from target population consisting of seventy-one mine discharges and one mine pump. 
in the basin have included hand loading, room-and-pillar (both full and partial extraction), and long wall (Leavitt et al., 2003). Mines around the northern and eastern perimeter of the basin are typically older, smaller, and shallower in comparison to those towards its center. The northern and eastern portions of the basin are dissected by the Monongahela and Youghiogheny Rivers, locally exposing the coal outcrop. Counties included in the study area are Marshall, Ohio, Monongalia, Marion, and Harrison, West Virginia, and Allegheny, Washington, Westmoreland, Greene, and Fayette, Pennsylvania.

\subsubsection{Mine Water Settings}

Mine geometry refers to location of mines above or below drainage (Mack et al., 2010). Older mines were developed in an up-dip direction to facilitate gravity drainage of water to mine openings (Winters and Capo, 2004). Water generally drained freely from the mine at one or more discharge locations. Above-drainage mining has been restricted in the Pittsburgh coal basin to outcrops along the eastern portion along the Monongahela River. Dates of closure of above-drainage mines ranged from about 1945-1965 (Smith, 1979). Above-drainage mining chemistry improves slightly over time but can remain acidic for long durations (Demchak et al., 2004).

As shallow coal resources became exhausted, mining shifted to below-drainage settings, with ultimate post-mining accumulation of water in the down-dip areas of the mine popularly referred to as "pools" (Donovan and Fletcher, 1999). As flooding continues these small pools merge into a single mine "pool," or hydraulically connected re-saturated mine void (Donovan and Fletcher, 1999). After flooding of below drainage mines is complete, distinct pressure-relief points develop in stream valleys over, or adjacent to, the flooded mines, allowing mine- 
contaminated ground water to discharge to the surface (Winters and Capo, 2004). Hydraulic head differences between mine pools, however, can induce leakage across coal barriers.

Interconnected mine pools may be indicated if several mines responding to recharge, discharge, and other stresses in unison (Perry and Hawkins, 2004). Interconnected mines throughout the coal basin often flood and act as a single flooded underground mine (Leavitt et al., 2003).

Pumping decreases hydraulic head and diverts water to treatment facilities or adjacent mines to prevent development of surface discharges. A groundwater control elevation is the water level maintained by pumping to prevent surface discharge, or breakout (Donovan and Fletcher, 1999). Pumping of deep underground active mines is necessary to prevent infiltration from discharging at the surface in an uncontrolled way. The recharge rate of underground mines increases as a result of subsidence fracturing of overburden over the coal, particularly in areas of thin overburden (Stoner, 1983; Booth et al., 1998; Booth, 2002). Thick overburden would inhibit infiltration and result in less recharge. Water levels of the pumped Clyde mine in Washington County, PA reflect annual pumping trends (Figure 3). Mines lying entirely below drainage that do not intersect topography develop a discharge only if a pressure relief point is established through boreholes or overburden fracturing.

\subsubsection{Mine Water Chemistry}

Coal mines closed prior to Clean Water Act (1972) and the Surface Mining and Control and Reclamation Act (1977) have no liable owner and may discharge without required chemical treatment. Discharges from pre-SMCRA mining are considered to originate from abandoned mine lands (AML), and many of these are acidic, caused by the oxidation and dissolution of pyrite (cubic $\mathrm{FeS}_{2}$ ), marcasite (orthorhombic $\mathrm{FeS}_{2}$ ), and/or pyrrhotite ( $\mathrm{FeS}$ ) (Equeenuddin et al., 


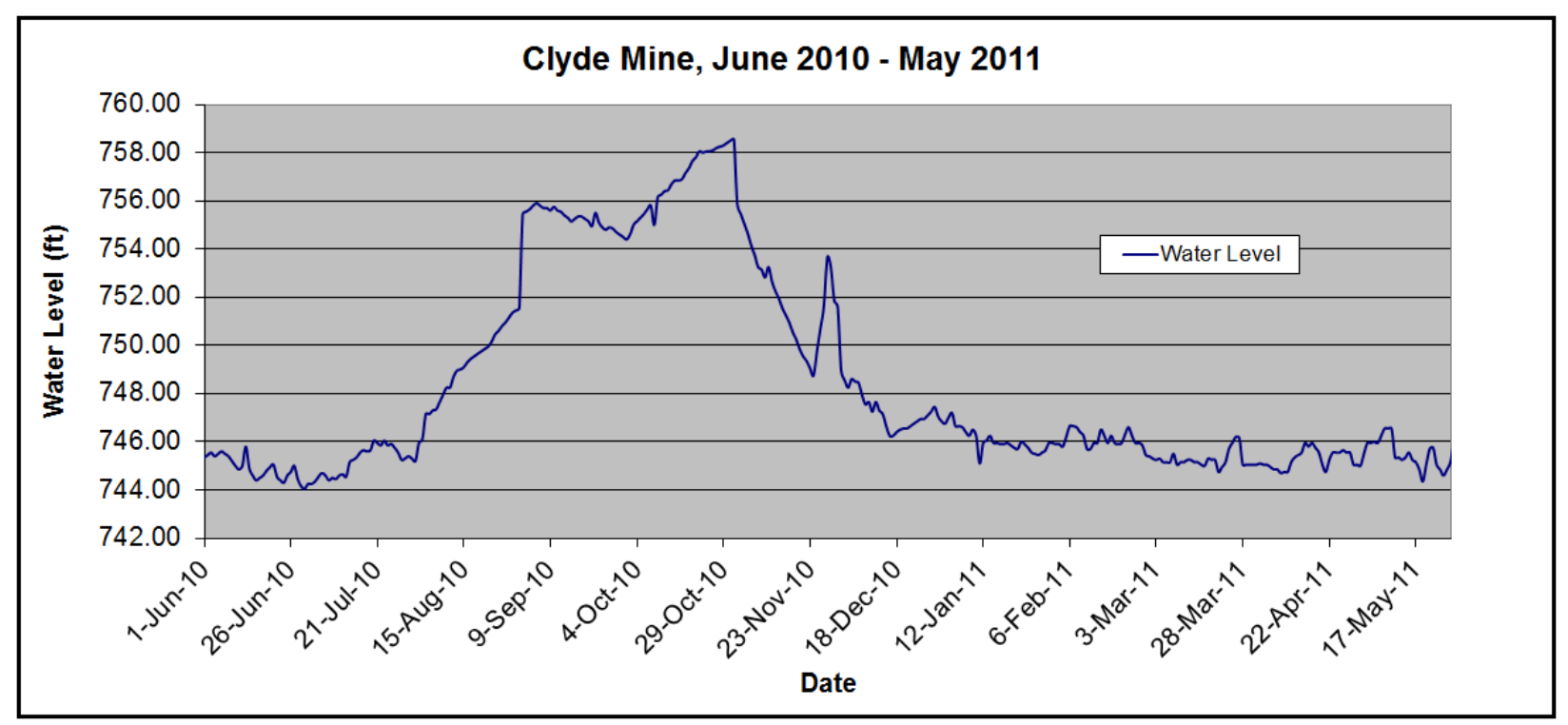

Figure 3: Annual pumping data from the Clyde mine, Clarksville, PA. 
2010). Mining activities expose sulfide minerals to oxygen and water, generating sulfuric acid (Equeenuddin et al., 2010). Pyrite dissolution and acid formation is, however, mitigated by the limitation of available oxygen and reduction in available pyrite surface area (Lambert et al., 2004). Highly acidic water may react with strata surrounding the coal resulting in further mineral dissolution.

The quantity and chemistry of water discharging from mines depend on a variety of factors (McDonough et al., 2005). Flooded mines separated by a continuous hydraulically-intact barrier generally have distinct pool elevations and discharge locations (Morris et al., 2008). Heterogeneity of recharge may influence chemistry of isolated pools throughout a mining complex (Stoertz et al., 2004).

Mines that are active or currently flooding are considered juvenile (Stiles et al., 2004). In flooded mines, the first flush water is highly acidic from high rates of pyrite dissolution as the mine fills, as well as from the dissolution of acid-generating salts on the walls of the mines (Lambert et al., 2004). Free-draining mines often maintain high acidity and high TDS for extended durations. As juvenile water matures in below-drainage mines, fully flooded hydrology develops and steady-state conditions are often achieved with recharge rates equal to discharge rates. The associated development of net alkaline discharges involves a series of processes including cation exchange, carbonate dissolution, and silicate weathering (Capo et al., 2001). High $\mathrm{Na}, \mathrm{SO}_{4}$, and alkalinity observed at end of flow paths indicate dissolution of soluble sulfate minerals and cation exchange (Perry, 2001). 


\subsection{Geologic Framework}

The structure of the Allegheny plateau is a Paleozoic-age sedimentary wedge resulting from several orogenic uplifts and accompanying transport of sediment to foreland basins. The Paleozoic units consist of multiple sequences of flat-lying sedimentary strata, including sandstone, conglomerate, siltstone, shale, claystone, limestone and coal (Miller et al., 1968). The bituminous coal deposits within the basin are folded numerous small synclines and anticlines, which trend in a northeast direction parallel to the Appalachian Mountains (Arndt et al., 1968). Age of rocks exposed at the surface becomes progressively younger in a northwest direction across West Virginia into southwestern Pennsylvania. The bedrock geology at the surface of the study area consists entirely of Pennsylvanian and Permian Period rock.

Within the Pennsylvanian the geology may be generalized as, from youngest to oldest the Monongahela, Conemaugh, Allegheny, and Pottsville groups (Ruppert et al., 2001; Tewalt et al., 2001; Figure 4). The Pittsburgh coal lies at the base of the Monongahela Group, and so the entire focus of this investigation is on that group. Monongahela-Group units are mostly freshwater sandstones and limestones overlying a laterally-continuous coal seam 1.5 to $2.5 \mathrm{~m}$ thick (5 to $8 \mathrm{ft}$.) (Stoner, 1983). However, sandstones and shales dominate Monongahela Group strata in the eastern portion of the basin (Stoner, 1983). The Monongahela Group includes the basal Pittsburgh coal with the Sewickley and Redstone coals approximately $27 \mathrm{~m}$ (90 ft.) above it (Figure 4). Pyritic overburden and underclays are common in stratigraphy surrounding Pennsylvanian coal beds. Fresh water limestones are more common in the western portion of the coal basin and the presence of carbonate rock in the overburden neutralizes acidity produced from pyrite oxidation (Demchak et al., 2004). 


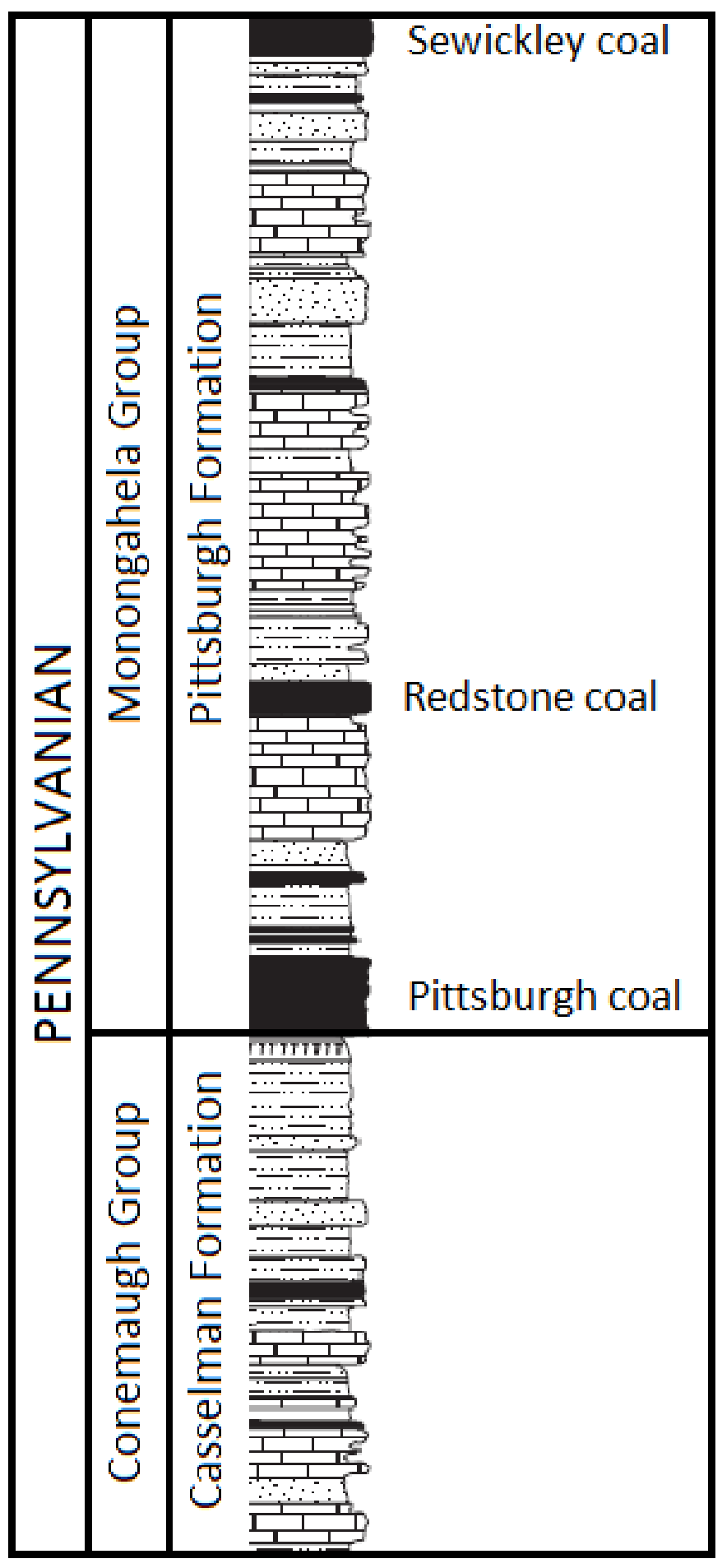

Figure 4: Stratigraphic column of bedrock in the study area. The Pittsburgh coal is immediately overlain by pyritic shale with limestone above (Cecil, 2012). 


\section{METHODOLOGY}

\subsection{Identification of Sampling Sites}

The target population includes closed mine discharges which meet mine water criteria set for this study and study area. From the target list, sites were selected that meet the following attributes:

(a) location within the study are and Pittsburgh seam mining

(b) discharge rate $\geq 378.5$ LPM (100 gpm), and

(c) accessible sampling site.

Target sites were visited and screened in the field prior to final inclusion in the sampling list. In the screening visit, the following was done.

(a) GPS acquisition of spatial data in NAD27 Conus datum,

(b) assessment of discharge volume and chemistry by visual observation, and

(c) assessment of accessibility regarding private property, state land, access roads, distance of hiking, ability to transport sampling equipment.

\subsection{Data Collection}

\subsubsection{Field and Sampling Parameters}

Sample collection employed the following protocols:

For each sampling site, a level work area was established and a GPS coordinate and photograph were obtained. The discharge source area was cleared and field parameters were measured in the discharge source with care taken to avoid atmospheric contamination and degassing. The natural flow rate was maintained and a Hanna HI $9025 \mathrm{pH}$ meter was submerged 
into the discharge to measure temperature (in degrees Celsius; ${ }^{\circ} \mathrm{C}$ ) and $\mathrm{pH}$. A YSI EC300 was submerged into the discharge to measure specific conductance (in micro Siemen per centimeter; $\mu \mathrm{S} / \mathrm{cm}$ ). A YSI 55 Dissolved Oxygen (DO) meter was submerged into the discharge to measure dissolved oxygen as concentration (in $\mathrm{mg} / \mathrm{L}$ ). A YSI pH/ORP meter was submerged into the discharge to measure the oxidation-reduction potential (ORP; in millivolts; $\mathrm{mV}$ ). One measurement per field sample was collected. The ORP was converted into an Eh value by the following equation:

$$
\text { Eh }=\text { Ehobs }+ \text { Ehzobell }- \text { Ehzobellobserved }
$$

Where $\mathrm{E}_{\mathrm{obs}}$ is the field electrode potential of the sample, $\mathrm{Eh}_{\text {zobell }}$ is $0.428-0.00022\left(\mathrm{~T}-25^{\circ} \mathrm{C}\right)$, and $\mathrm{Eh}_{\text {zobell-observed }}$ is the lab-measured electrode potential of the standard Zobell solution (Nordstrom and Wilde, 2005). The Eh was converted to electron activity (pe) by:

$$
p e=\frac{F}{2.303 R T} E h
$$

Where F is Faraday's constant $\left(96.42 \mathrm{~kJ}\right.$ volt $\left.^{-1} \mathrm{eq}^{-1}\right), \mathrm{R}$ is the ideal gas constant $\left(8.314 \mathrm{~J} \mathrm{~mol}^{-1} \mathrm{~K}^{-1}\right)$ and $\mathrm{T}$ is temperature $(\mathrm{K})$.

All meters were calibrated daily by manufacturer protocol. Two-point calibration of $\mathrm{pH}$ was conducted with $\mathrm{pH}=4$ and $\mathrm{pH}=7$ buffer solutions. One-point calibration of electrical specific conductance was conducted with $1.413 \mu \mathrm{S} / \mathrm{cm}$ solution of $0.01 \mathrm{M} \mathrm{KCl}$. Two-point calibration of dissolved oxygen was conducted at $100 \%$ saturation in a built-in saturation chamber and $0 \%$ saturation in an oversaturated sodium metabisulfate solution. A post field equipment check was conducted to record instrumental drift occurring per sampling day (Table 1). 


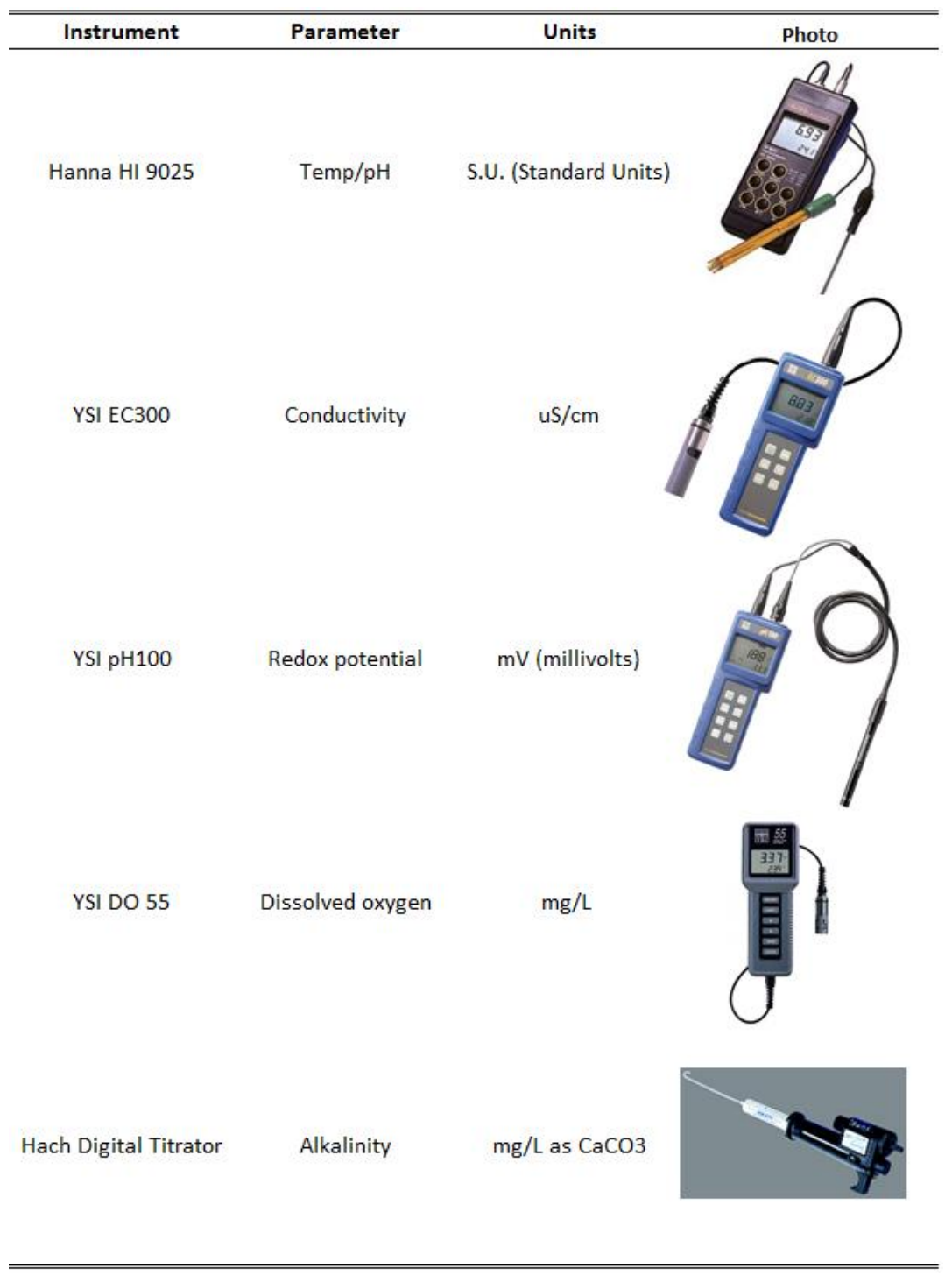

Table 1: Instrumentation and equipment employed for collection of field data. 
Measurement of alkalinity was conducted by field titration with $1.6 \mathrm{~N}$ sulfuric acid in a 250mL Erlenmeyer flask to $\mathrm{pH}$ endpoint 4.5. Temperature and $\mathrm{pH}$ were monitored with a Hanna HI $9025 \mathrm{pH}$ meter during the titration.

One field sample per site was collected by insertion of a 60 cubic centimeter (cc) syringe into the discharge source with care taken to reduce de-gassing and atmospheric contamination. The sample was filtered through a 0.45 micron membrane filter and split between two manufacturer sterilized $60 \mathrm{~mL}$ polyethylene collection bottles. Cation samples were acidified using a volume of trace-metal grade nitric acid equal to $1 \%$ of the sample volume (0.6mL/60mL). Acidification occurred post-field per sampling day. Anion samples underwent no acid preservation. Samples were stored on ice in the field and refrigerated during storage. Lab analysis was conducted by the NRCCE Analytical Laboratory.

\subsubsection{Lab Analysis}

Lab analysis employed the following protocols:

(a) inductively coupled plasma optical emission spectroscopy (ICP-OES) for determination of total: $\mathrm{Fe}, \mathrm{Al}, \mathrm{Mn}, \mathrm{Na}, \mathrm{K}, \mathrm{Ca}, \mathrm{Mg}, \mathrm{Ba}, \mathrm{Be}, \mathrm{Se}, \mathrm{S}$, and $\mathrm{Sr}$ reported as $\mathrm{mg} / \mathrm{L}$. The selected analytes are either common mine water contaminants, are ecologically harmful, or are indicators of non-mining related contamination. The concentration of sulfate was calculated from total sulfur and reported as mg/L.

(b) ion chromatography (IC) for determination of the major anions $\mathrm{NO}_{3}, \mathrm{Br}, \mathrm{Cl}$, and $\mathrm{F}$ reported as $\mathrm{mg} / \mathrm{L}$.

Cation analysis employed a Varian Vista Pro CCD Simultaneous ICP-OES and anion analysis employed a Dionex GP40 gradient pump, AS40 automated sampler, LC20 chromatography 
enclosure, ED40 electrochemical detector, and AS4A column set using Na-CO3-HCO3 eluent. Samples were submitted with standard quality control measures. Analytes occurring below the equipment detection limits (e.g., censored data) were represented as half the minimum detection limit (MDL) for the purpose of any statistical analysis performed.

\subsection{Equilibrium Calculations}

Analysis of mineral equilibria for reactions influencing mine chemistry utilized the aqueous thermodynamic model and database of PHREEQC (Parkhurst and Appelo, 1999). Molarities of chemical species, molarities of aqueous complexes, and saturation indices of common mining-related minerals were computed and exported to a selected output file. An apparent equilibrium constant of $10^{-18}$ for schwertmannite was added to the 'PHREEQC.dat' database, based on results of Bigham et al. (1996). Total molar concentrations of the chemical constituents was selected from the PHREEQC output file and included in the data matrix as molar concentration in place of chemical constituents reported from the laboratory as part per million $(\mathrm{mg} / \mathrm{L})$.

\subsection{Statistical Analysis}

Statistical analysis consisted of univariate and bivariate techniques applied using $\mathrm{R}$ statistical software (R Core Team, 2012). Univariate frequency distributions are displayed using violin and Q-Q plots (Murrell, 2011). Bivariate statistical methods consisted of (a) correlation (b) principal component analysis, and (c) cluster analysis. Correlation and principal component analysis were performed on a dataset consisting of standardized chemical data and hydrologic attributes. Cluster analysis has various options for clustering and employed the following:

(a) standardized chemical constituents, 
(b) agglomerative hierarchal cluster analysis of selected constituents,

(c) Ward minimum linkage method as similarity measure to distinguish clusters, and

(d) squared Euclidean distance as the metric for distance between centroids of clusters.

Two attributes were added to quantify hydrogeological conditions of the mines from which samples were obtained. 'Saturation' may be defined as the percentage of mine volume that is flooded, based on mine-maps and flooded areas reported of McCoy (2002), updated for mines whose flooding levels had increased since 2005. This study employs a variable 'Flooding index" which is the normalized extent of flooding measured in the vertical:

$$
\text { Flooding Index }=\frac{\left(\text { Elev }_{\text {discharge }}-\text { Elev }_{\min }\right)}{\left(\text { Elev }_{\max }-\text { Elev }_{\min }\right)}
$$

Where $\operatorname{Elev}_{\max }$ is the maximum elevation within a mine, $\operatorname{Elev}_{\min }$ is the minimum elevation within a mine, and $\mathrm{Elev}_{\text {discharge }}$ is the elevation from which mine water discharges from the mine. 


\section{RESULTS}

\subsection{Compilation and speciation of chemical constituents}

Seventy-two mine discharges from fifty mines were sampled during June to October 2012 (Table 2). Twenty-nine percent of these samples had one or more constituents below the minimum detection limit (MDL) for the technique (Table 3). For statistical analysis, 0.5 times the MDL was employed for these censored values.

Using $\mathrm{pH}$, alkalinity, and analytical results, the charge balance error (CBE) was calculated using equivalent concentrations of cations and anions, as follows:

$$
C B E=\frac{\left(\sum \text { cations }- \text { Sanions }\right)}{\left(\sum \text { cations }+ \text { Eanions }\right)}
$$

Where $\sum$ cations and Eanions are the sum of equivalent concentrations for measured analytes. In early runs, large errors were detected for $\mathrm{Fe}, \mathrm{Na}, \mathrm{Ca}$, and $\mathrm{Mg}$ in undiluted samples with concentrations in excess of the working range for the method. After re-runs with dilution, a maximum absolute error of $21.2 \%$ was used as the quality-control rejection criterion for CBE. Observed values of $\mathrm{CBE}$ in retained samples ranged from $-21.2 \%$ to $14.6 \%$.

Alkalinity is reported in Table 4 in $\mathrm{mg} / \mathrm{L}$ as $\mathrm{CaCO}_{3}$. Alkalinity was not measured in samples with $\mathrm{pH}<4.5$ because these have too little alkalinity to be detected by titration. There is, however, a small concentration (on the order of $<0.05 \mathrm{M}$ ) of $\mathrm{HCO}_{3}{ }^{-}$even at such low $\mathrm{pH}$. For use in equilibrium calculations, this alkalinity was estimated from a $\mathrm{pH}$-pC diagram for carbon species with closed-system equilibria fit to actual data for the fifty-five samples with $\mathrm{pH}>4.5$ (Figure 5). $\mathrm{HCO}_{3}{ }^{-}$concentrations for low $\mathrm{pH}$ samples were interpolated from the fitted closedsystem model and ranged from $0.09 \mathrm{mg} / \mathrm{L}$ to $8.2 \mathrm{mg} / \mathrm{L}$ as $\mathrm{CaCO}_{3}$ (Table 4). Error in these 


\begin{tabular}{|c|c|c|c|c|c|c|}
\hline MINENAME & ID & shortID & CBE & Sampling Date & ReRun & ReRun \\
\hline Chiefton & West Fork 2 & WF2 & -8.02 & 06/2012 & & \\
\hline Raybert & West Fork 5 & WF5 & -15.81 & 06/2012 & & \\
\hline Ruby \#2 & Ruby 2d & RU2D & -9.57 & 06/2012 & & \\
\hline Ruby \#2 & Ruby $2 c$ & RU2C & -16.74 & 06/2012 & & \\
\hline Gates & Gates & GATE & 11.53 & 06/2012 & & \\
\hline Palmer & Adah & ADAH & 12.91 & 06/2012 & & \\
\hline Palmer & Palmer & PALM & 14.64 & 06/2012 & & \\
\hline Odonald 1 \& 2 & Grays Landing & GRAY & -5.24 & 06/2012 & & \\
\hline Maiden \#1 & Maidsville & MDVL & -8.89 & $06 / 2012$ & & \\
\hline Canyon Nester & Smith 06b & SM6B & -8.43 & $06 / 2012$ & & \\
\hline Peacock & Smith 03a & SM3A & -21.24 & 06/2012 & & \\
\hline Export & Export & EXPO & -9.79 & $06 / 2012$ & & \\
\hline Delmont & Borland2 & BOR1 & -14.10 & 06/2012 & & \\
\hline Delmont & Borland1 & BOR2 & -12.18 & 06/2012 & & \\
\hline Boston Gas \& Coal & MD7x & MD7x & -10.81 & $06 / 2012$ & & \\
\hline Maiden \#1 & Taylorstown 2B SW & T2BSW & -13.81 & 06/2012 & & \\
\hline Maiden \#1 & Taylorstown 2B NE & T2BNE & -7.24 & 06/2012 & & \\
\hline Maiden \#1 & Taylorstown 2A & TAY2A & -8.24 & $06 / 2012$ & & \\
\hline Maiden \#3 & Maiden 3B & MAD3B & -9.43 & $06 / 2012$ & & \\
\hline Maiden \#3 & Maiden $3 \mathrm{~A}$ & MAD3A & -10.61 & 06/2012 & & \\
\hline Maxwell & Luzerne & LUZE & -9.61 & 06/2012 & & \\
\hline Chamoni & Brownsville & BRWN & 0.80 & 06/2012 & & \\
\hline Karen & Karen & KARN & -2.03 & $06 / 2012$ & & \\
\hline Maple Glenn & Maple Glenn & MAGL & -6.04 & 06/2012 & & \\
\hline Boston Gas \& Coal & Iron Falls & IFAL & -10.34 & $06 / 2012$ & & \\
\hline Boston Gas \& Coal & Douglas Run & DOUG & -7.24 & 06/2012 & & \\
\hline Marchand & Marchand & MARC & -7.50 & 06/2012 & & \\
\hline Lyons Run & Lyons Run & LYON & -12.52 & $06 / 2012$ & & \\
\hline Lyons Run & Coal Run & COAL & -14.10 & 06/2012 & & \\
\hline Guffey & Guffey & GUFF & -5.04 & 06/2012 & & \\
\hline Boston Gas \& Coal & East Monongahela & EMON & -5.78 & 06/2012 & & \\
\hline Boston Gas \& Coal & MD6 West & MD6W & -1.88 & $06 / 2012$ & & \\
\hline Guffey & Guffey Lower & GUFL & -0.59 & 06/2012 & & \\
\hline Unknown & MD4 & MD4 & -16.98 & 06/2012 & & \\
\hline Unknown & MD2 & MD2 & -11.54 & $06 / 2012$ & & \\
\hline Catsburg & Catsburg & CATS & -6.44 & 06/2012 & & \\
\hline Catsburg & Carroll & CARR & -1.01 & 06/2012 & & \\
\hline Boston Gas \& Coal & MD10 Lower & M10L & -9.51 & 06/2012 & & \\
\hline Boston Gas \& Coal & MD9 & MD9 & -0.49 & 06/2012 & & \\
\hline Boston Gas \& Coal & MD6 & MD6 & -8.42 & 06/2012 & & \\
\hline Boston Gas \& Coal & MD7 & MD7 & -10.48 & $06 / 2012$ & & \\
\hline Eclipse & Granville Hollow & GRAN & -5.78 & 07/2012 & ICP-S and IC & \\
\hline Vesta \#1 \& \#2 & Vesta \#1 \&\#2 & VES12 & -3.00 & 07/2012 & ICP-S and IC & \\
\hline Eclipse & Eclipse1 & ECL1 & -5.74 & 07/2012 & ICP-S and IC & \\
\hline Eclipse & Eclipse2 & ECL2 & -6.66 & 07/2012 & ICP-S and IC & \\
\hline Eclipse & Eclipse3 & ECL3 & -7.46 & 07/2012 & ICP-S and IC & \\
\hline Vesta \#3 & Vesta \#3 & VES3 & -3.95 & 07/2012 & ICP-S and IC & \\
\hline Langloth & Langeloth & LANG & -11.65 & $07 / 2012$ & ICP-S and IC & \\
\hline Erie & Erie North & ERNO & -9.90 & 07/2012 & ICP-S and IC & \\
\hline Unknown & Surface Mine & SURF & -13.69 & 07/2012 & ICP-S and IC & ICP-All \\
\hline Pitts \#3 & MD1000gpm & MDTH & -10.54 & 07/2012 & ICP-S and IC & ICP-All \\
\hline Montour \#1 & Gladden & GLAD & -3.65 & 07/2012 & ICP-S and IC & \\
\hline Essen \#3 & Presto-Sygan & PREST & -13.50 & 07/2012 & ICP-S and IC & ICP-All \\
\hline Montour \#4 & Wingfield Pines & WING & 1.55 & 07/2012 & ICP-S and IC & \\
\hline Unknown & McGlaughlin Run & MCGLA & -12.83 & 07/2012 & ICP-S and IC & \\
\hline Unknown & Coal Run West & COALW & 3.73 & 07/2012 & ICP-S and IC & \\
\hline Nixon \#5 & Saltwell & SALT & -20.35 & $07 / 2012$ & ICP-S and IC & \\
\hline Scott \#2 & Owens 34b & O34B & -6.59 & 07/2012 & ICP-S and IC & \\
\hline Erie & Erie South & ERSO & -8.80 & 07/2012 & ICP-S and IC & \\
\hline Mine $A$ & Prospect & PROS & -8.29 & 07/2012 & ICP-S and IC & \\
\hline Mine \#54 \& \#23 & Backyard & BACK & -6.67 & 07/2012 & ICP-S and IC & \\
\hline Pursglove/Osage & Core Pump & CORE & -12.65 & 07/2012 & ICP-S and IC & ICP-All \\
\hline Mine \#26 & Norway & NORW & -6.03 & 07/2012 & ICP-S and IC & \\
\hline Dravo & Aluminum Falls & AFAL & -17.81 & 07/2012 & ICP-S and IC & ICP-All \\
\hline Unknown & Herminie & HERM & -18.04 & 07/2012 & ICP-S and IC & \\
\hline Scott \#2 & Owens 34bx & O34Bx & -10.81 & 07/2012 & ICP-S and IC & \\
\hline Unknown & Convent & CONV & -6.06 & 08/2012 & & \\
\hline Wheeling Valley & Cherry Run & CHER & -13.50 & 08/2012 & & \\
\hline 5th Street & 5th Street & 5ST & -4.47 & 08/2012 & & \\
\hline Richland & Richland & $\mathrm{RICH}$ & -9.39 & 08/2012 & & \\
\hline Isabella & Isabella & ISAB & -2.57 & 08/2012 & & \\
\hline Clyde & Clyde & CLYD & -3.34 & $10 / 2012$ & & \\
\hline
\end{tabular}

Table 2: Sample site nomenclature and quality control analytical data. 'ID' represents the sample which originated from a 'minename' and has an abbreviated 'shortID.' Sampling date refers to field collection date; CBE is analytical charge balance error. 'Re-run' indicates re-run samples and the parameters re-run. 


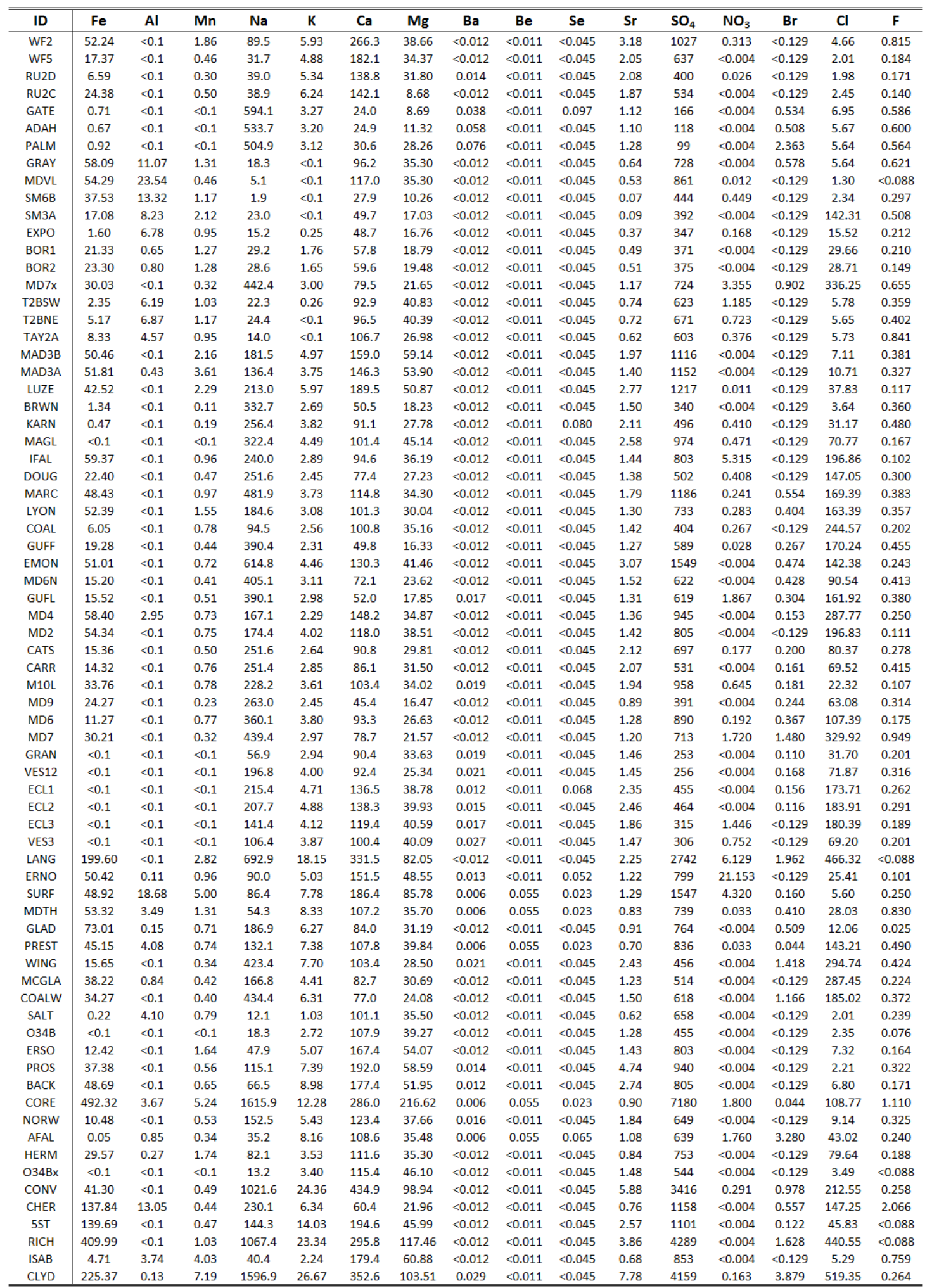

Table 3: Raw lab data indicating values below the analytical minimum detection limit. Data is reported as mg/L. 


\begin{tabular}{cccc}
\hline \hline \multicolumn{4}{c}{ Alkalinity as $\mathrm{CaCO}_{3 \text { (mg/L) }}$} \\
\hline ID & pH & Field & Calculated \\
\hline Grays Landing & 2.71 & 0.000 & 0.1374 \\
Maidsville & 2.83 & 0.000 & 0.1811 \\
Smith 06b & 2.57 & 0.000 & 0.0995 \\
Smith 03a & 2.84 & 0.000 & 0.1853 \\
Export & 3.01 & 0.000 & 0.2741 \\
Borland1 & 4.49 & 0.000 & 8.1687 \\
Taylorstown 2B SW & 3.70 & 0.000 & 1.3401 \\
Taylorstown 2B NE & 2.69 & 0.000 & 0.1312 \\
Taylorstown 2A & 2.74 & 0.000 & 0.1472 \\
Surface Mine & 3.55 & 0.000 & 0.9493 \\
Saltwell & 3.93 & 0.000 & 2.2723 \\
Cherry Run & 3.63 & 0.000 & 1.1410 \\
Isabella & 3.27 & 0.000 & 0.4986 \\
\hline \hline
\end{tabular}

Table 4: Calculated alkalinity for acidic sites $(\mathrm{pH}<4.5)$ based on bicarbonate concentrations interpolated from the $\mathrm{pH}$ vs. activity plot. 


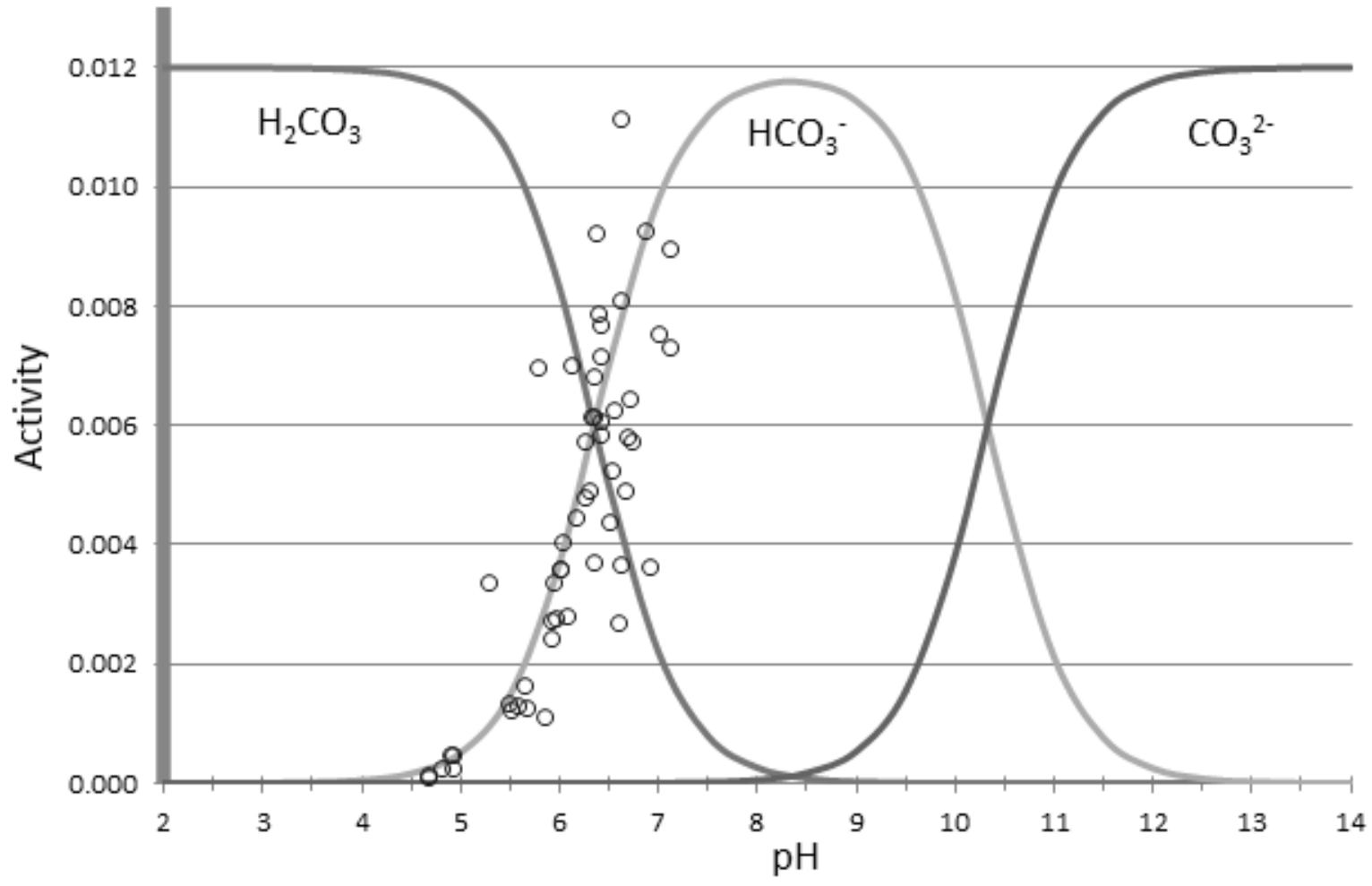

Figure 5: Plot of $\mathrm{pH}$ vs. activity. Circles represent field alkalinity data from alkaline sites $(\mathrm{pH}>$ 4.5) plotted against $\mathrm{pH}$. Bicarbonate equilibria under closed system conditions were fitted to the field alkalinity data to interpolate alkalinity for acidic sites $(\mathrm{pH}<4.5)$. 
estimates result from the assumptions that (a) DIC for these acidic mine waters is similar to DIC for the non-acidic discharges, and (b) that all mines display similar DIC.

The speciation of iron was conducted using PHREEQC and Eh estimated from field ORP measurements. PHREEQC output included aqueous species concentrations and activities. Ferric iron concentrations were negligibly small for every mine discharge except Smith 06b, Taylorstown 2A, and Taylorstown 2B, for which speciated ferric concentrations $(35.3 \mathrm{mg} / \mathrm{L}, 7.1$ $\mathrm{mg} / \mathrm{L}$, and $4.1 \mathrm{mg} / \mathrm{L}$, respectively) were larger than ferrous. Ferric iron concentrations for the other samples ranged were $<2 \mathrm{mg} / \mathrm{L}$. Assuming closed-system conditions (Figure 5), extrapolated carbon dioxide partial pressures for acidic $(\mathrm{pH}<4.5)$ mine discharges were in the range of $10^{-0.45}$ atmospheres (atm), while PHREEQC-calculated partial pressures for net-alkaline mine discharges ranged from $10^{-0.7}$ atm to $10^{-1.6}$ atm (points in Figure 5; Table 5).

\subsection{Statistical Analysis}

\subsubsection{Constituent Distributions}

Distributions of pH, pe, alkalinity, $\mathrm{Fe}^{2+}, \mathrm{Fe}^{3+}, \mathrm{Al}, \mathrm{Mn}, \mathrm{Na}, \mathrm{K}, \mathrm{Ca}, \mathrm{Mg}, \mathrm{Ba}, \mathrm{Be}, \mathrm{Se} \mathrm{Sr}, \mathrm{SO}_{4}$, $\mathrm{NO}_{3} \mathrm{Cl}, \mathrm{Br}$, and $\mathrm{F}$ concentrations were visualized using violin plots (Murrell, 2011), a method for presenting probability density and parameters of a sample set (Figure 6). The center line is the median and the ticks bracketing it are the 25th and 75th percentiles. Maxima and minima of each variable are also shown, as well as extreme outliers beyond the bracket ticks.

Determination of "outliers" is an arbitrary process, and these may simply be extreme values within a non-normally distributed variable, in which case values should be treated in the same manner as other observations (Grubbs, 1969). 


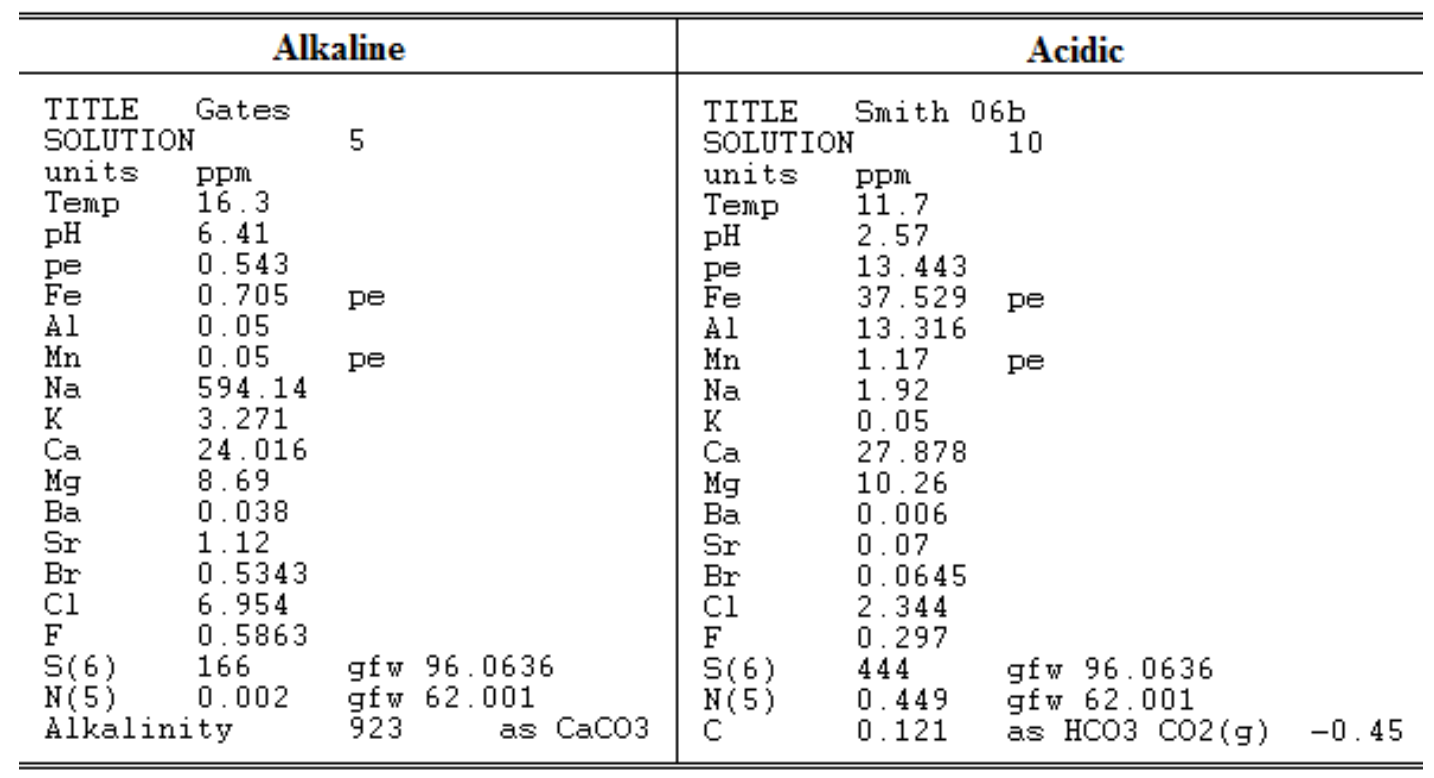

Table 5: PHREEQC input file for alkaline and acidic samples. $\mathrm{pCO}_{2}$ for acidic samples was calculated by Henry's Law. 

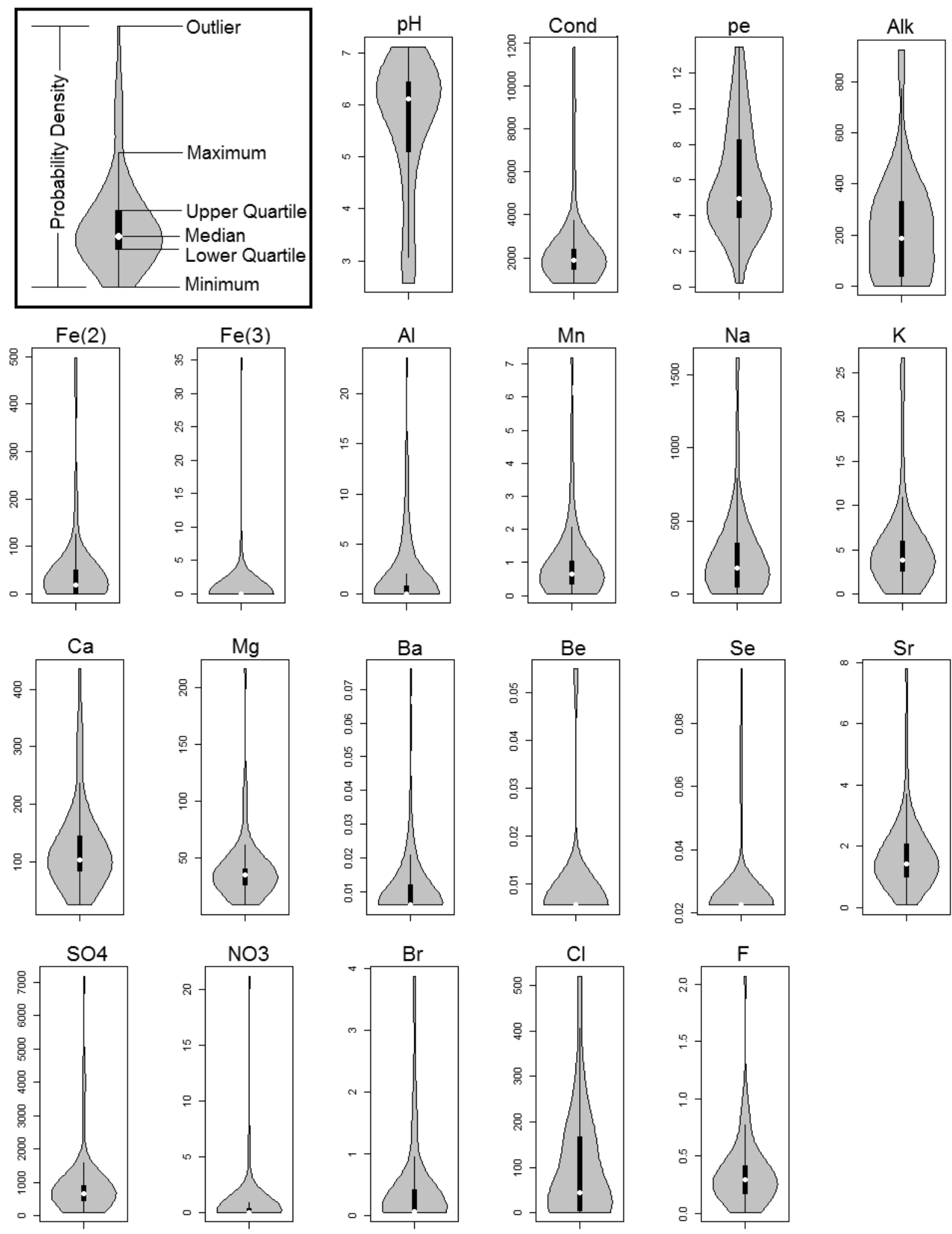

Figure 6: Probability density of total ion concentrations, as violin plots (Murrell, 2011). 
$\mathrm{Fe}^{2+}, \mathrm{Mn}, \mathrm{Na}, \mathrm{K}, \mathrm{Ca}, \mathrm{Mg}, \mathrm{Sr}, \mathrm{SO}_{4}, \mathrm{Cl}$, and $\mathrm{F}$ concentrations lie well above their minimum detection limits (MDLs) and display positive skew (e.g., are non-normal) with one or more outliers. $\mathrm{Fe}^{3+}, \mathrm{Al}, \mathrm{Ba}, \mathrm{Be}, \mathrm{Se}, \mathrm{NO}_{3}$, and $\mathrm{Br}$ concentrations lie commonly below their MDLs and display positive skew with several outliers. pe, alkalinity, and chloride display symmetrical, normal-like probability densities. $\mathrm{pH}$ displays slightly negative skew with a somewhat bimodal distribution.

The constituents $\mathrm{pH}$, pe, alkalinity, $\mathrm{Fe}^{2+}, \mathrm{Fe}^{3+}, \mathrm{Al}, \mathrm{Mn}, \mathrm{Na}, \mathrm{K}, \mathrm{Ca}, \mathrm{Mg}, \mathrm{Ba}, \mathrm{Be}, \mathrm{Se} \mathrm{Sr}$, $\mathrm{SO}_{4}, \mathrm{NO}_{3} \mathrm{Cl}, \mathrm{Br}$, and $\mathrm{F}$ concentrations were analyzed for normality utilizing Q-Q plots (Murrell, 2011; Figure 7). Q-Q plots illustrate normality or deviation from normality graphically by plotting theoretical sample quartiles against sampled quartiles. If the sample density is skewed to the right, then the sample quartiles close to one will lie to the right of where normality would place them, and similarly for the sample quartiles close to zero (Murrell, 2011). Log-normal (leptokurtic) distributions have more observations at greater distance from the mean than a normal distribution of the same standard deviation. Thus log-normal distributions produce a QQ plot with a sigmoidal shape, having crossed the diagonal normality line three times (Murrell, 2011).

The Q-Q plots for $\mathrm{pH}$ displays negative skew while those for $\mathrm{Mn}, \mathrm{Na}, \mathrm{K}, \mathrm{Ca}, \mathrm{Mg}, \mathrm{Sr}$, and F show positive skew. The Q-Q plots for specific conductance, pe, alkalinity, $\mathrm{Fe}^{2+}$, and $\mathrm{SO}_{4}$ are log-normal. For $\mathrm{Fe}^{3+}, \mathrm{Al}, \mathrm{Ba}, \mathrm{Be}, \mathrm{Se}, \mathrm{NO}_{3}$, and $\mathrm{Br}$, the $\mathrm{Q}-\mathrm{Q}$ plots display positive skew with high density at the MDL. Due to the observed non-normality, these concentrations were converted to Z-scores prior to bivariate analysis (R Core Team, 2012) and the resulting dataset was used for correlation, principal component, and cluster analysis. 

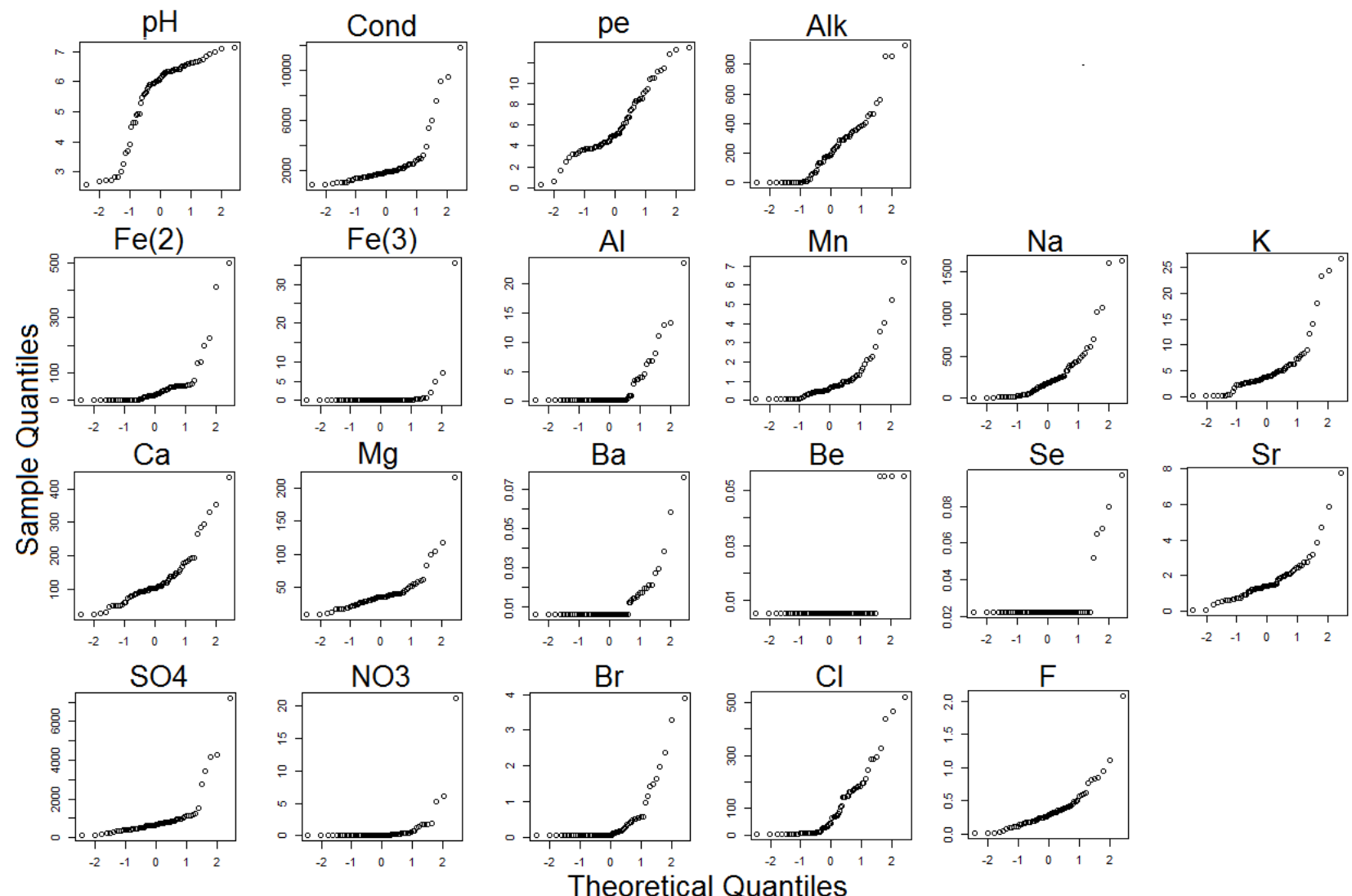

Figure 7: Normality, or lack thereof, of total ion concentrations, as Q-Q plots (Murrell, 2011). 


\section{$\underline{3.2 .2 \text { Bivariate relationships }}$}

Bivariate correlation was calculated between $\mathrm{pH}$, pe, alkalinity, $\mathrm{Fe}^{2+}, \mathrm{Fe}^{3+}, \mathrm{Al}, \mathrm{Mn}, \mathrm{Na}$, $\mathrm{K}, \mathrm{Ca}, \mathrm{Mg}, \mathrm{Ba}, \mathrm{Sr}, \mathrm{SO}_{4}, \mathrm{Br}, \mathrm{Cl}$, saturation, and depth (Figure 8 and 9, Table 6). The strongest positive correlations $(\mathrm{R}>0.90)$ are between $\mathrm{Fe}^{2+}, \mathrm{Mg}$, and $\mathrm{SO}_{4}$. Weaker, but still notable, correlations were observed for $\mathrm{Na}, \mathrm{K}, \mathrm{Ca}, \mathrm{Mg}, \mathrm{Sr}$, and $\mathrm{SO}_{4}$. Slight correlation is observed between $\mathrm{Ba}$ and alkalinity. $\mathrm{pH}$ is negatively correlated with both $\mathrm{Al}$ and pe. No correlation is observed between $\mathrm{Fe}^{2+}, \mathrm{Mg}$, and $\mathrm{SO}_{4}$ with $\mathrm{Fe}^{3+}$ and $\mathrm{Al}$. Alkalinity and $\mathrm{pH}$ also show no correlation with $\mathrm{Fe}^{2+}, \mathrm{Mg}$, and $\mathrm{SO}_{4}$ and the observed small $\mathrm{R}$-values $(\mathrm{R}<0.10)$ are considered random.

Principal component analysis (PCA) was conducted on a standardized (Z-score) dataset including $\mathrm{pH}$, pe, alkalinity, $\mathrm{Fe}^{2+}, \mathrm{Fe}^{3+}, \mathrm{Al}, \mathrm{Mn}, \mathrm{Na}, \mathrm{K}, \mathrm{Ca}, \mathrm{Mg}, \mathrm{Ba}, \mathrm{Sr}, \mathrm{SO}_{4}, \mathrm{Br}, \mathrm{Cl}$, saturation, and depth (Figures 10-16). The component scores for PC1, PC2, and PC3 are displayed in Figures 13 and 15, Table 7. PC1 shows positive scores for nineteen samples and negative scores for thirteen samples. PC2 shows positive scores for twenty-eight samples and negative scores for seventeen samples. PC3 shows positive scores for seven samples and negative scores for twenty-one samples. The scree plot for PCA indicates that four eigenvectors exceed the 1.0 criterion of Kaiser (1960) (Figure 10), though the fourth falls within the sampling uncertainty in the Kaiser 1.0 parameter.

Comparison of eigenvector loadings for PCA2 vs. PCA1 suggests three distinct trends in covariation (Figure 13). $\mathrm{PC} 1$ has high positive loadings for $\mathrm{Fe}^{3+}, \mathrm{Al}$, and pe, and high negative loadings from constituents of salinity, i.e. $\mathrm{Na}, \mathrm{Cl}, \mathrm{Sr}$, and $\mathrm{Br}$. $\mathrm{PC} 2$ has high positive loadings for 


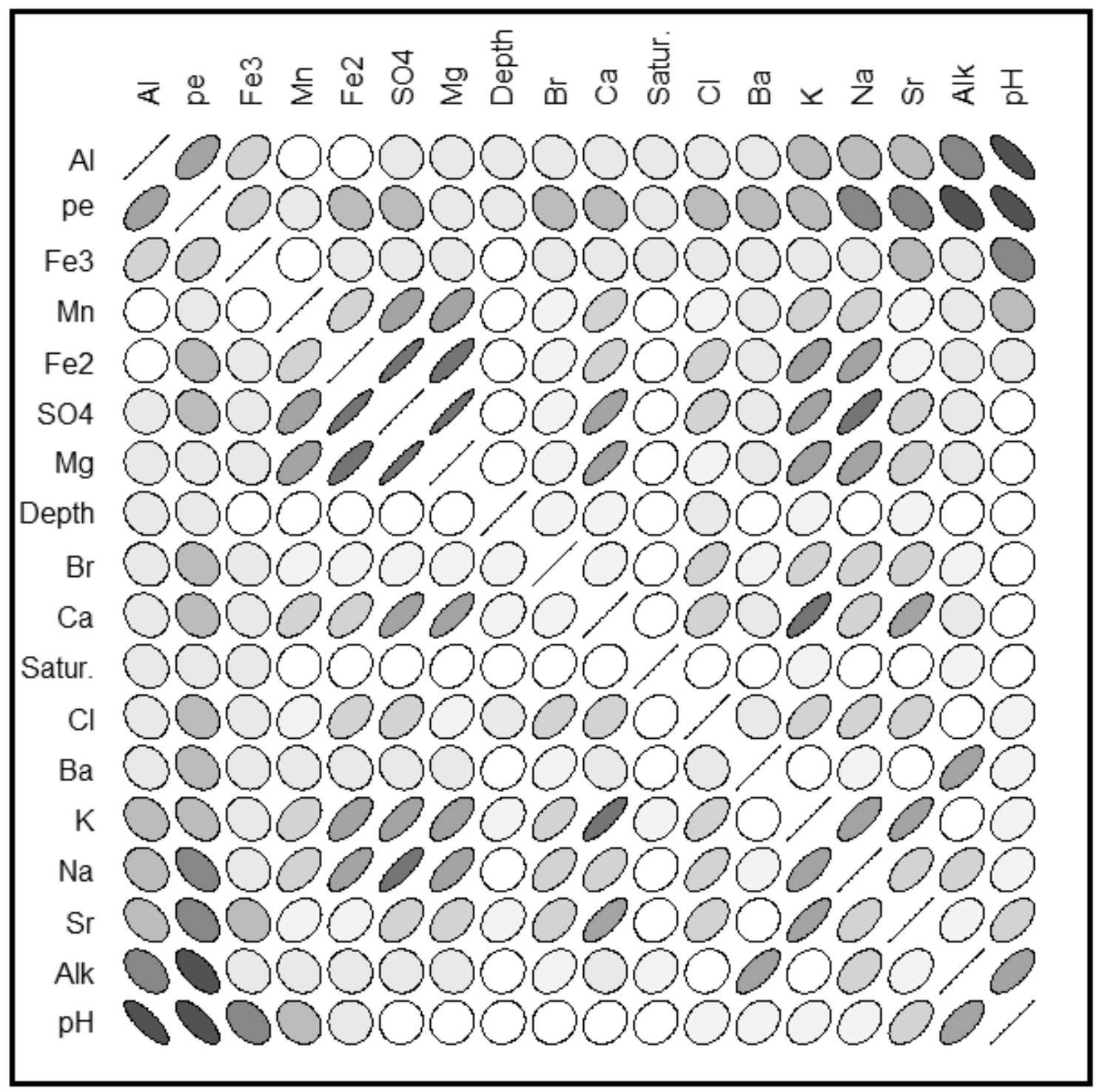

Figure 8: Results of Pearson's product moment correlation. Greater elongation and darker shading of the ellipse indicates stronger correlation. Ellipse tilted right indicates positive correlation; ellipse tilted left indicates negative correlation. 


\begin{tabular}{|c|c|c|c|c|c|c|c|c|c|c|c|c|c|c|c|c|c|c|}
\hline & Al & pe & $\mathrm{Fe}^{3+}$ & Mn & $\mathrm{Fe}^{2+}$ & $\mathrm{SO}_{4}$ & $\mathrm{Mg}$ & Depth & $\mathrm{Br}$ & $\mathrm{Ca}$ & Satur. & $\mathrm{Cl}$ & $\mathrm{Ba}$ & K & $\mathrm{Na}$ & $\mathrm{Sr}$ & Alk & $\mathrm{pH}$ \\
\hline Al & 1.00 & & & & & & & & & & & & & & & & & \\
\hline pe & 0.61 & 1.00 & & & & & & & & & & & & & & & & \\
\hline $\mathrm{Fe}^{3+}$ & 0.42 & 0.42 & 1.00 & & & & & & & & & & & & & & & \\
\hline Mn & 0.07 & -0.01 & 0.02 & 1.00 & & & & & & & & & & & & & & \\
\hline $\mathrm{Fe}^{2+}$ & 0.04 & -0.24 & -0.08 & 0.56 & 1.00 & & & & & & & & & & & & & \\
\hline $\mathrm{SO}_{4}$ & -0.01 & -0.24 & -0.07 & 0.66 & 0.91 & 1.00 & & & & & & & & & & & & \\
\hline $\mathrm{Mg}$ & -0.06 & -0.15 & -0.13 & 0.64 & 0.83 & 0.94 & 1.00 & & & & & & & & & & & \\
\hline Depth & -0.12 & -0.16 & 0.07 & 0.19 & 0.01 & 0.10 & 0.15 & 1.00 & & & & & & & & & & \\
\hline $\mathrm{Br}$ & -0.12 & -0.24 & -0.08 & 0.31 & 0.30 & 0.33 & 0.22 & 0.21 & 1.00 & & & & & & & & & \\
\hline $\mathrm{Ca}$ & -0.17 & -0.21 & -0.16 & 0.54 & 0.59 & 0.75 & 0.77 & 0.28 & 0.30 & 1.00 & & & & & & & & \\
\hline Satur. & -0.17 & -0.14 & 0.00 & 0.04 & 0.15 & 0.14 & 0.19 & 0.06 & 0.20 & 0.15 & 1.00 & & & & & & & \\
\hline $\mathrm{Cl}$ & -0.19 & -0.24 & -0.14 & 0.27 & 0.46 & 0.44 & 0.32 & -0.02 & 0.53 & 0.40 & 0.17 & 1.00 & & & & & & \\
\hline $\mathrm{Ba}$ & -0.18 & -0.29 & -0.07 & -0.10 & -0.11 & -0.13 & -0.10 & 0.15 & 0.34 & -0.18 & 0.17 & -0.06 & 1.00 & & & & & \\
\hline K & -0.27 & -0.40 & -0.17 & 0.41 & 0.65 & 0.73 & 0.66 & 0.30 & 0.58 & 0.83 & 0.21 & 0.57 & 0.03 & 1.00 & & & & \\
\hline $\mathrm{Na}$ & -0.22 & -0.52 & -0.14 & 0.49 & 0.72 & 0.82 & 0.69 & 0.11 & 0.54 & 0.54 & 0.20 & 0.59 & 0.23 & 0.71 & 1.00 & & & \\
\hline $\mathrm{Sr}$ & -0.39 & -0.43 & -0.21 & 0.29 & 0.29 & 0.46 & 0.42 & 0.25 & 0.43 & 0.73 & 0.15 & 0.44 & 0.10 & 0.77 & 0.56 & 1.00 & & \\
\hline Alk & -0.45 & -0.64 & -0.19 & -0.17 & -0.08 & -0.02 & -0.07 & 0.08 & 0.32 & -0.01 & 0.21 & 0.12 & 0.70 & 0.20 & 0.47 & 0.35 & 1.00 & \\
\hline $\mathrm{pH}$ & -0.80 & -0.73 & -0.41 & -0.25 & -0.02 & 0.03 & 0.05 & 0.08 & 0.11 & 0.17 & 0.18 & 0.22 & 0.27 & 0.31 & 0.32 & 0.52 & 0.65 & 1.00 \\
\hline
\end{tabular}

Figure 9: Results of Pearson's product moment correlation. Correlations $(r>0.70)$ are shaded. 


\begin{tabular}{ccc|ccc}
\hline \hline $\mathbf{r}$ & \multicolumn{2}{c|}{ Parameters } & $\mathbf{r}$ & \multicolumn{2}{c}{ Parameters } \\
\hline-0.80 & $\mathrm{pH}$ & $\mathrm{Al}$ & 0.94 & $\mathrm{Fe}^{2+}$ & $\mathrm{SO}_{4}$ \\
-0.73 & $\mathrm{pH}$ & $\mathrm{pe}$ & 0.91 & $\mathrm{Mg}$ & $\mathrm{SO}_{4}$ \\
& & & 0.83 & $\mathrm{Fe}^{2+}$ & $\mathrm{Mg}$ \\
& & & 0.83 & $\mathrm{Ca}$ & $\mathrm{K}$ \\
& & 0.82 & $\mathrm{Na}$ & $\mathrm{SO}_{4}$ \\
& & 0.77 & $\mathrm{Ca}$ & $\mathrm{Mg}$ \\
& & 0.77 & $\mathrm{~K}$ & $\mathrm{Sr}$ \\
& & 0.75 & $\mathrm{Ca}$ & $\mathrm{SO}_{4}$ \\
& & 0.73 & $\mathrm{Ca}$ & $\mathrm{Sr}^{2}$ \\
& & 0.73 & $\mathrm{~K}$ & $\mathrm{SO}_{4}$ \\
& & 0.72 & $\mathrm{Na}$ & $\mathrm{SO}_{4}$ \\
& & 0.71 & $\mathrm{Na}$ & $\mathrm{K}$ \\
& & 0.70 & $\mathrm{Ba}$ & $\mathrm{Alk}^{2}$ \\
\hline \hline
\end{tabular}

Table 6: Results of Pearson's product moment correlation. 


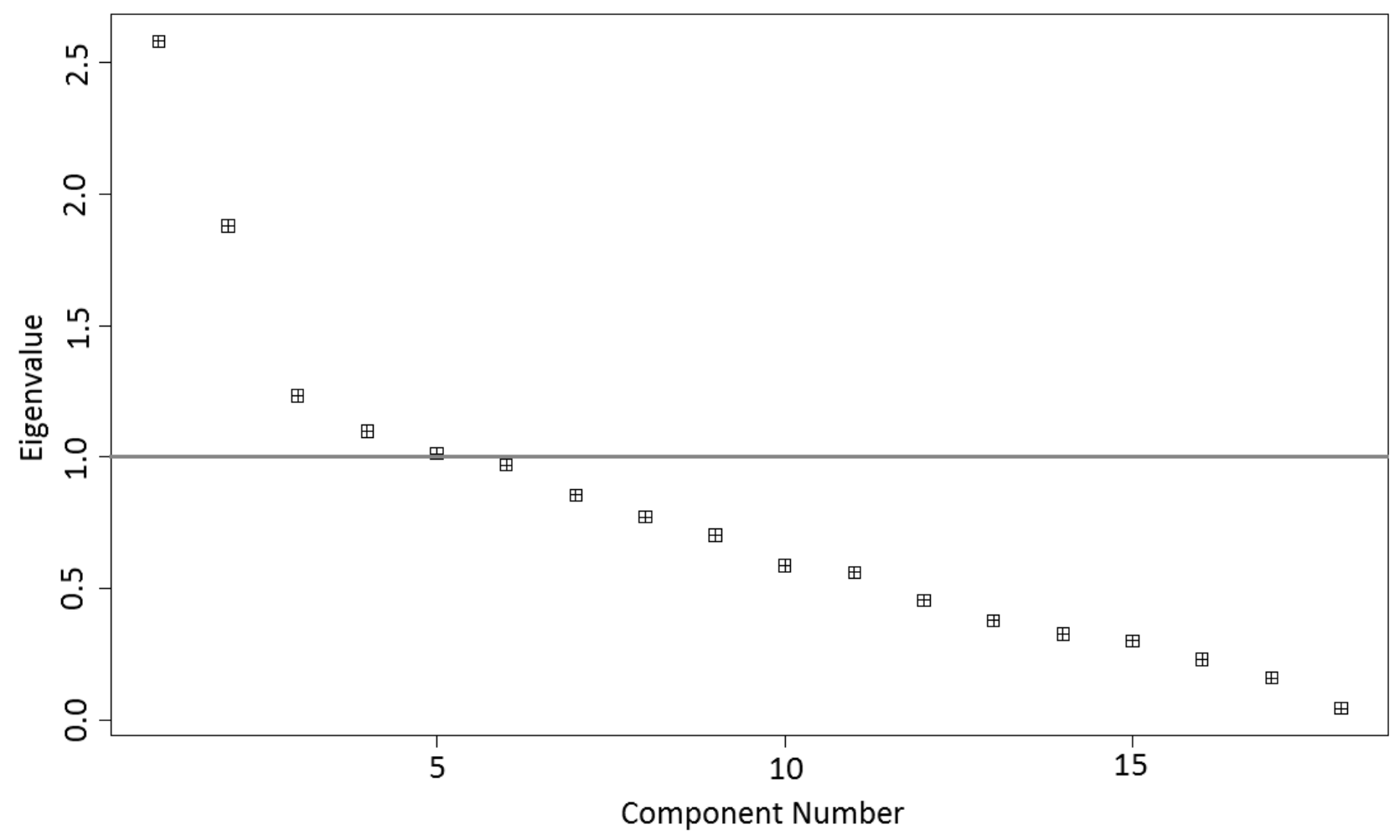

Figure 10: Scree plot of eigenvalues for principal component analysis (PCA) of mine-water chemistry. Horizontal line $=$ Kaiser cutoff criterion for significant eigenvectors. 


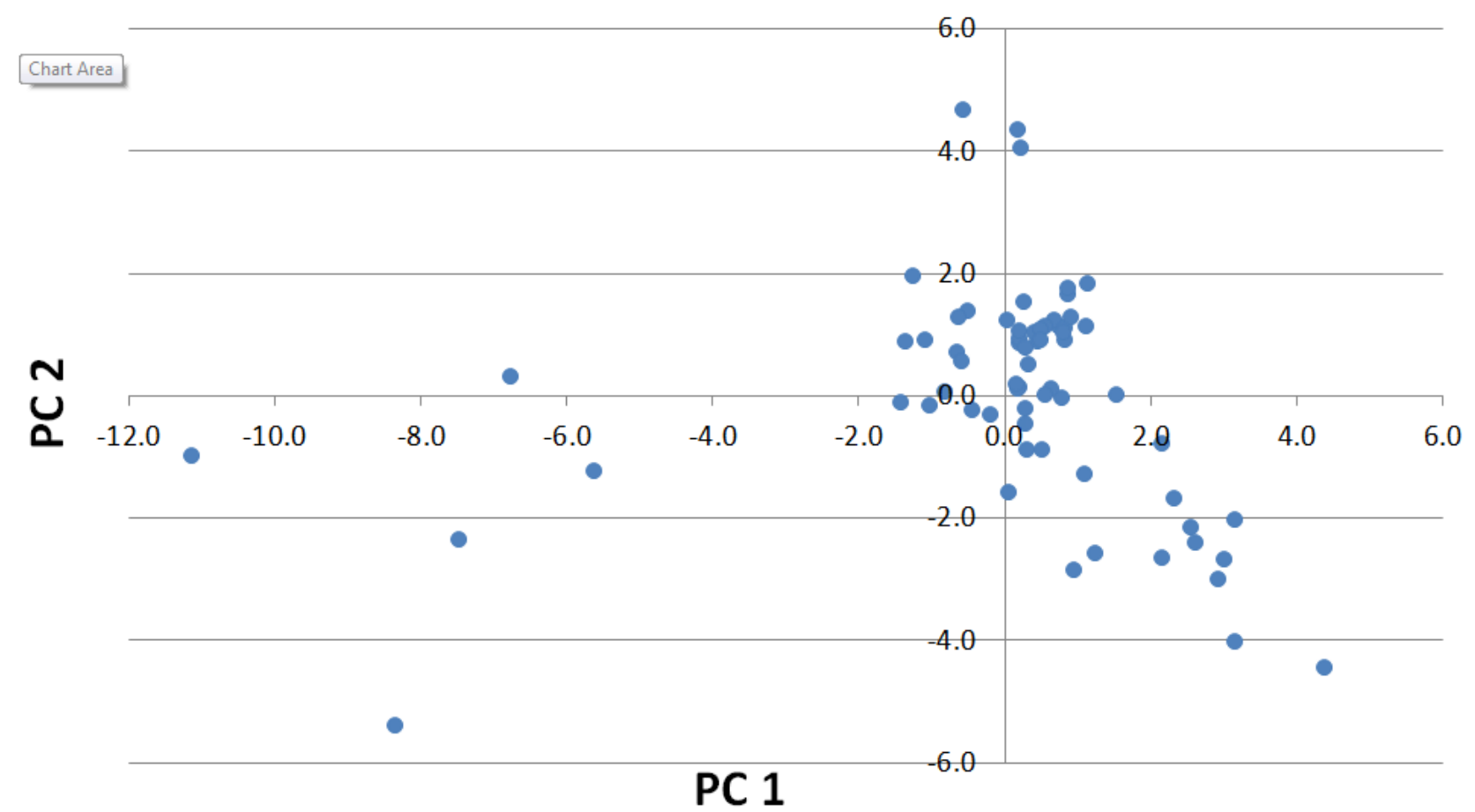

Figure 11: Biplot of PC1 scores vs. PC2 scores. 


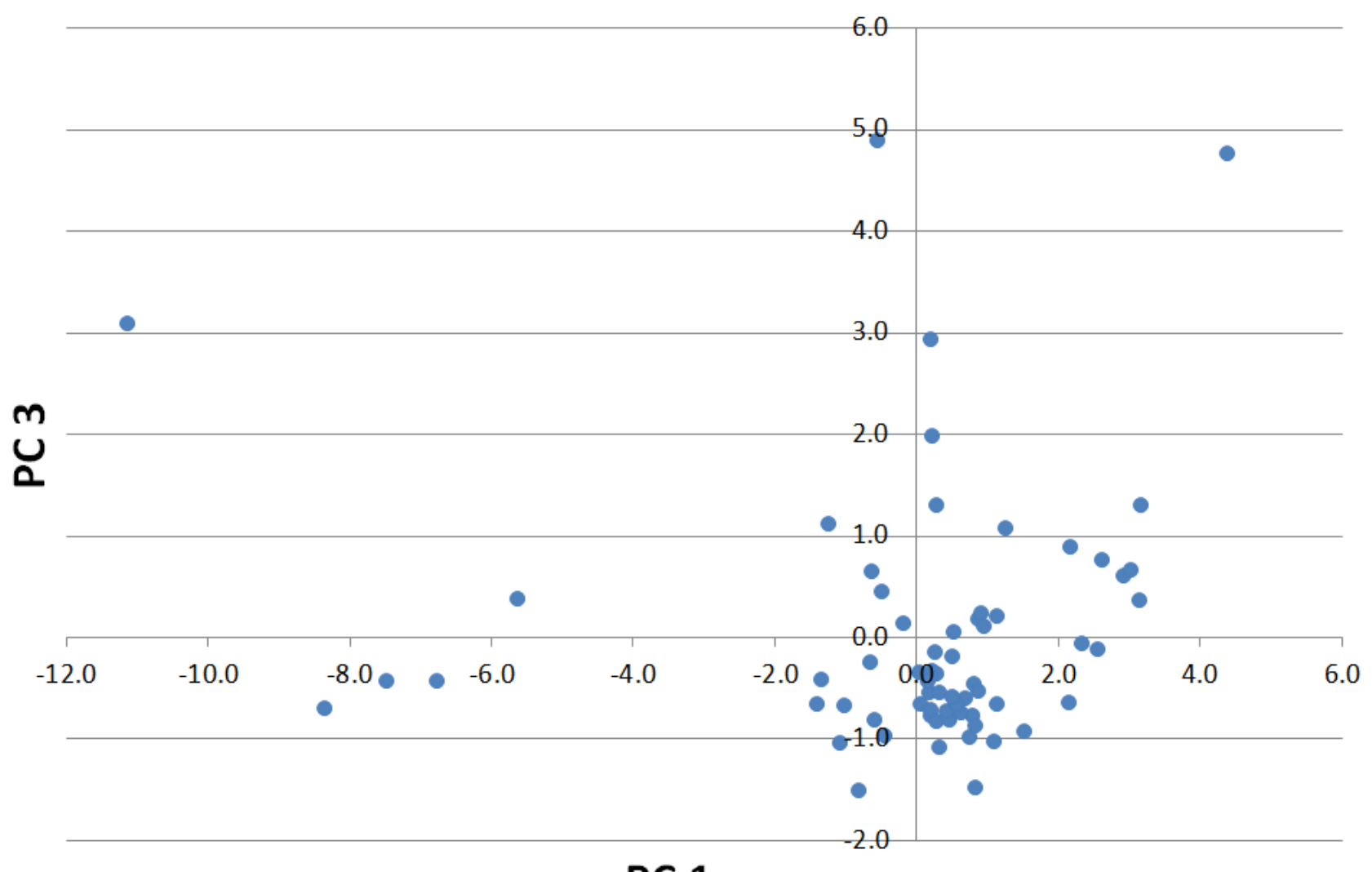

PC 1

Figure 12: Biplot of PC1 scores vs. PC3 scores. 


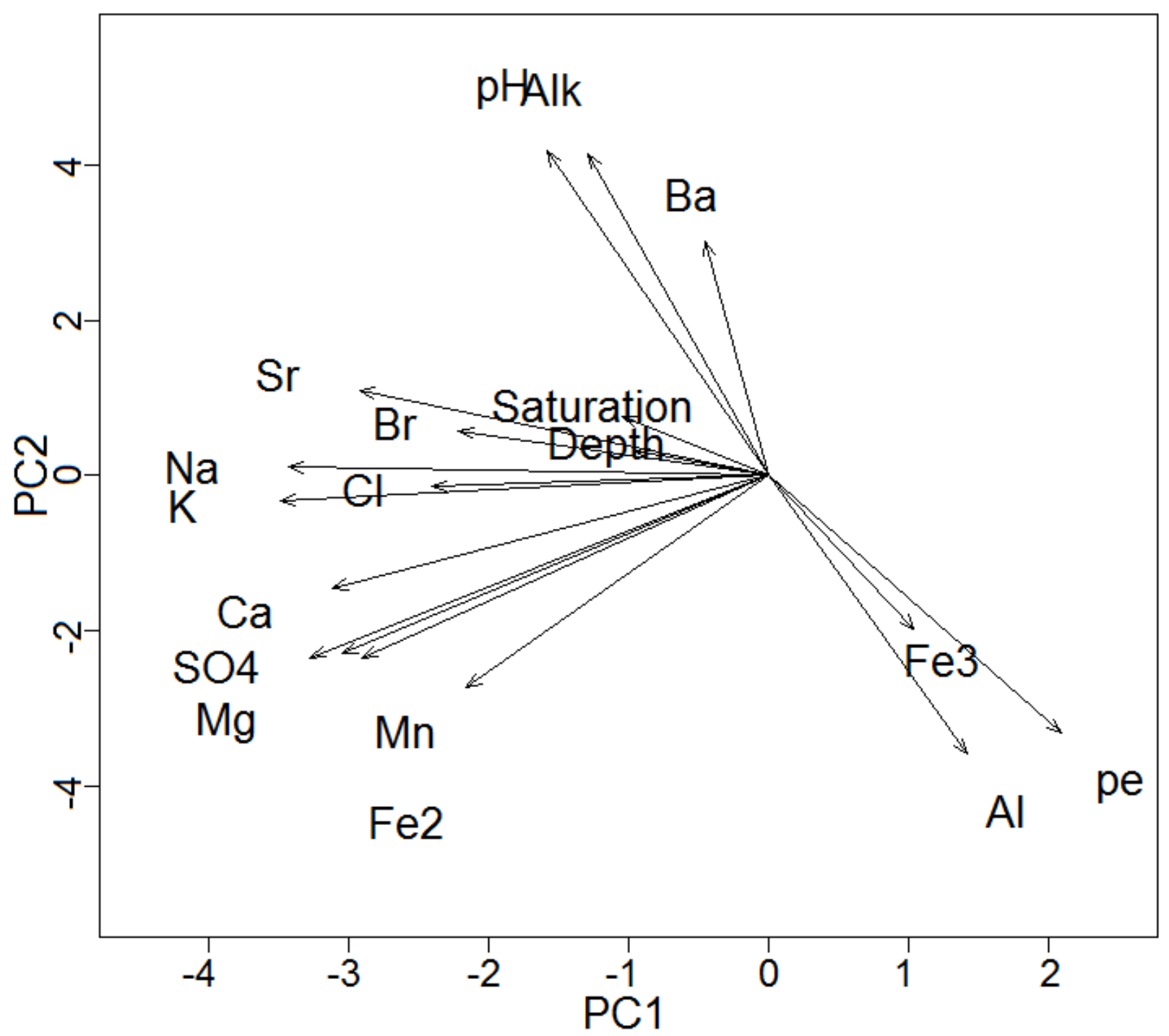

Figure 13: PCA component loadings of standardized chemical data for PC1 vs. PC2. 


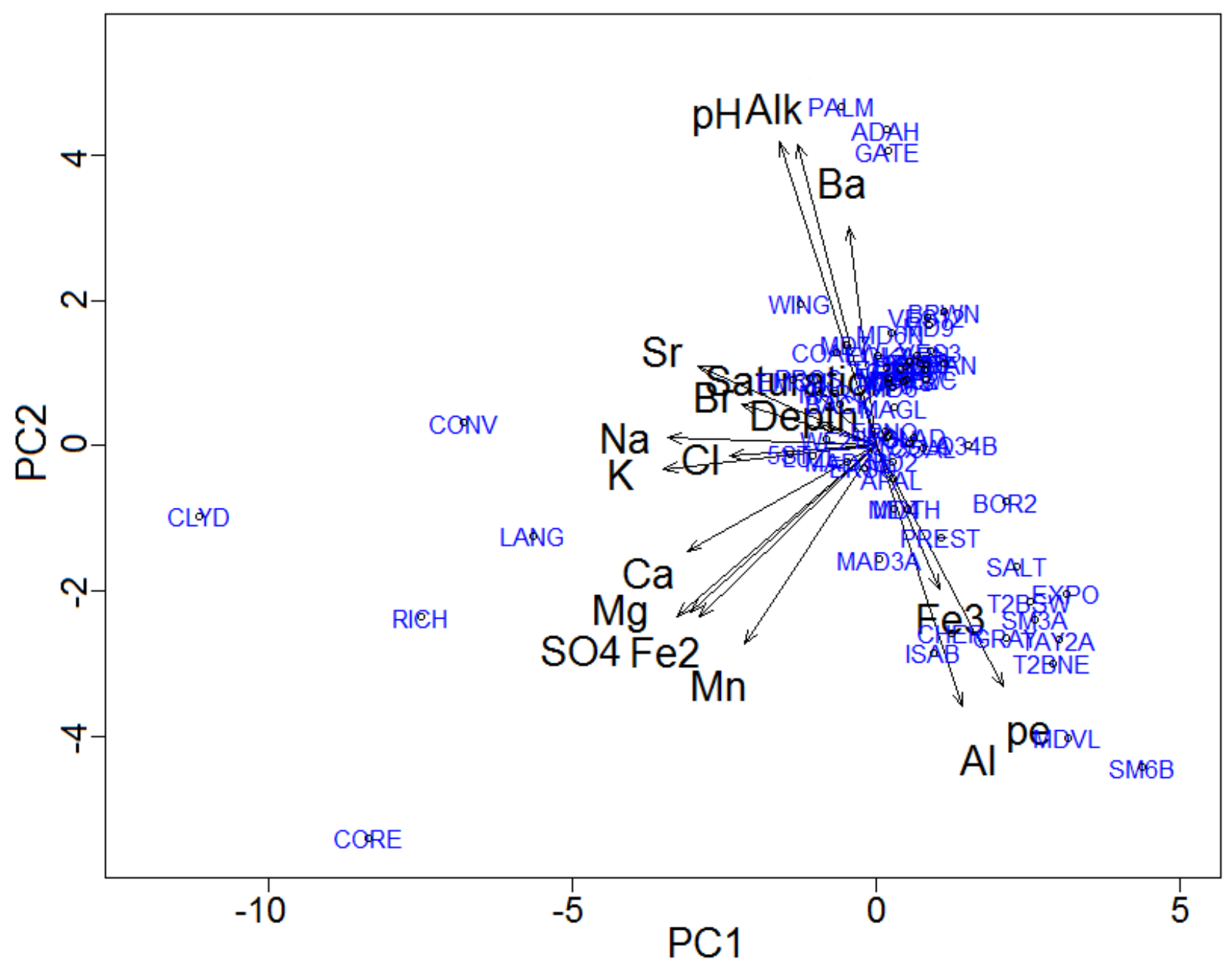

Figure 14: PCA scores of standardized chemical data for PC1 vs. PC2. 


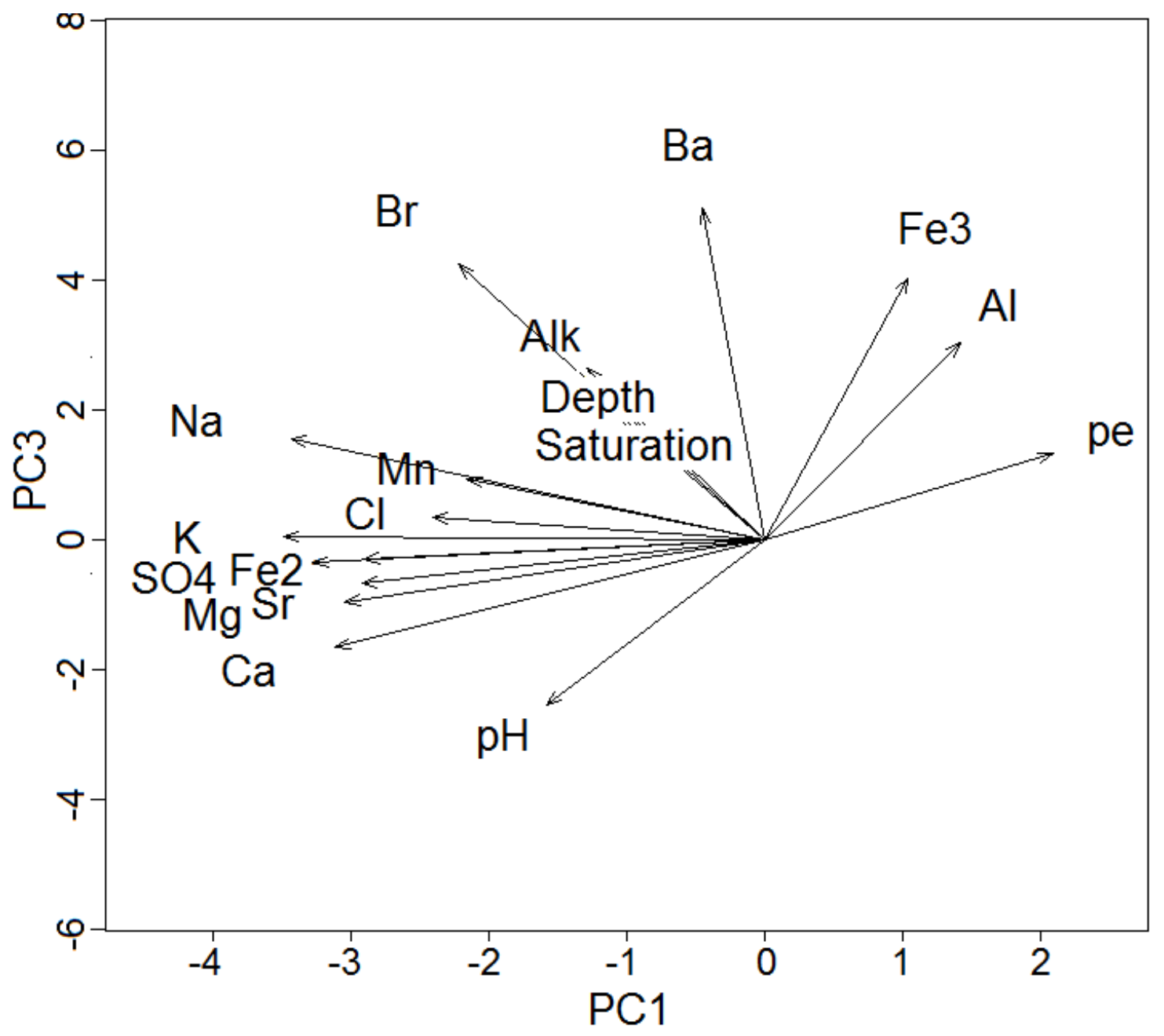

Figure 15: PCA component loadings of standardized chemical data for PC1 vs. PC3. 


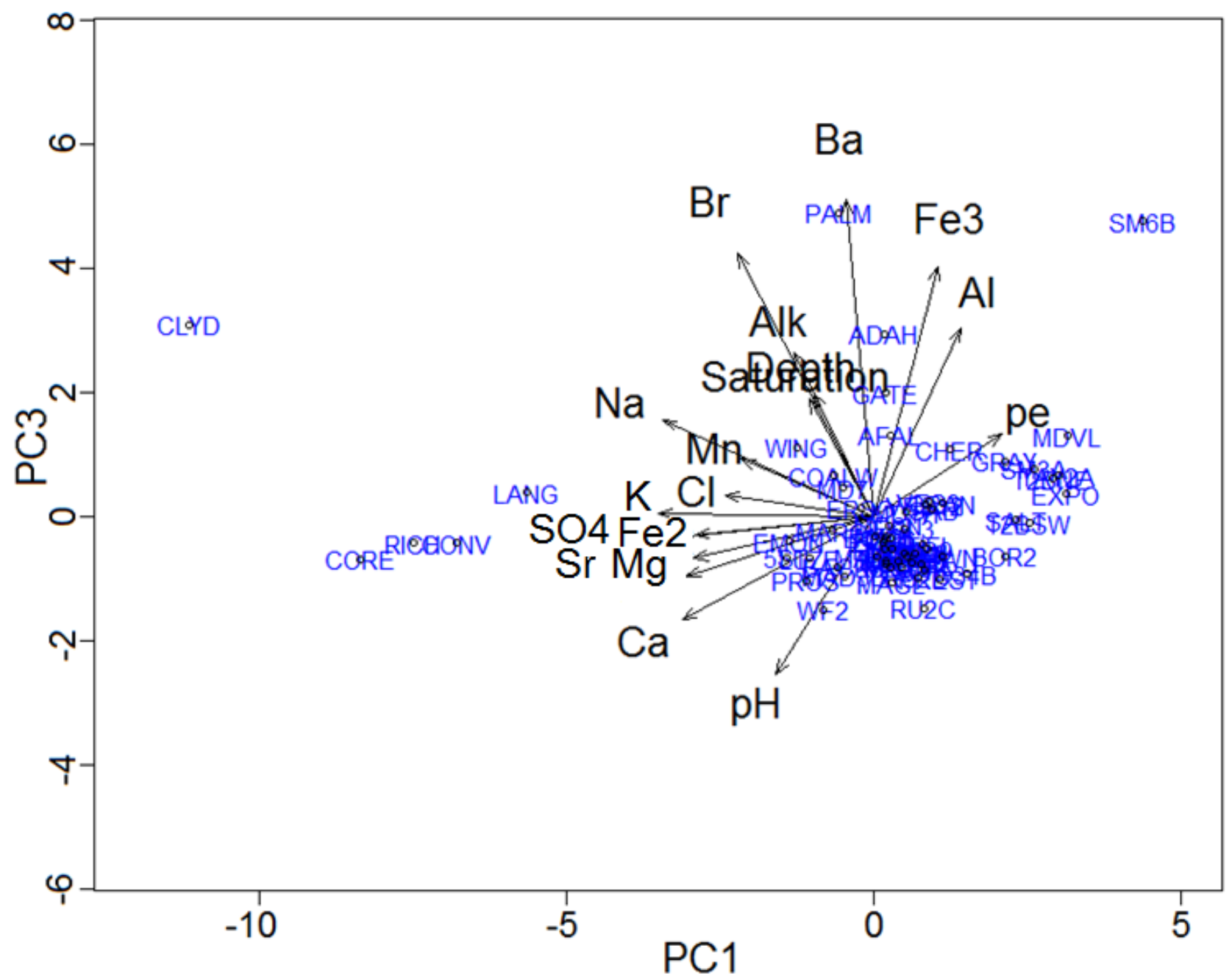

Figure 16: PCA scores of standardized chemical data for PC1 vs. PC3. 


\begin{tabular}{|c|c|c|c|}
\hline & PC1 & PC2 & PC3 \\
\hline WF2 & -0.825 & 0.084 & -1.503 \\
\hline WF5 & 0.191 & 0.860 & -0.763 \\
\hline RU2D & 0.735 & 1.146 & -0.981 \\
\hline RU2C & 0.817 & 0.910 & -1.474 \\
\hline GATE & 0.207 & 4.058 & 1.994 \\
\hline ADAH & 0.183 & 4.350 & 2.937 \\
\hline PALM & -0.568 & 4.676 & 4.895 \\
\hline GRAY & 2.153 & -2.642 & 0.893 \\
\hline MDVL & 3.151 & -4.018 & 1.302 \\
\hline SM6B & 4.371 & -4.426 & 4.763 \\
\hline SM3A & 2.617 & -2.390 & 0.766 \\
\hline EXPO & 3.139 & -2.031 & 0.367 \\
\hline BOR2 & 2.147 & -0.770 & -0.634 \\
\hline T2BSW & 2.549 & -2.148 & -0.111 \\
\hline T2BNE & 2.911 & -2.991 & 0.612 \\
\hline TAY2A & 3.005 & -2.675 & 0.663 \\
\hline MAD3B & -0.458 & -0.221 & -0.960 \\
\hline MAD3A & 0.047 & -1.564 & -0.651 \\
\hline LUZE & -1.033 & -0.144 & -0.670 \\
\hline BRWN & 1.134 & 1.843 & -0.653 \\
\hline KARN & 0.670 & 1.251 & -0.590 \\
\hline MAGL & 0.313 & 0.530 & -1.072 \\
\hline IFAL & 0.193 & 0.143 & -0.714 \\
\hline DOUG & 0.538 & 1.151 & -0.638 \\
\hline MARC & -0.664 & 0.726 & -0.235 \\
\hline LYON & 0.180 & 0.111 & -0.533 \\
\hline COAL & 0.784 & -0.023 & -0.769 \\
\hline GUFF & 0.819 & 1.121 & -0.866 \\
\hline EMON & -1.357 & 0.902 & -0.408 \\
\hline MD6N & 0.256 & 1.553 & -0.145 \\
\hline GUFL & 0.801 & 1.049 & -0.450 \\
\hline MD4 & 0.309 & -0.865 & -0.532 \\
\hline MD2 & 0.268 & -0.213 & -0.816 \\
\hline CATS & 0.451 & 0.892 & -0.814 \\
\hline CARR & 0.406 & 1.050 & -0.718 \\
\hline M10L & 0.204 & 0.936 & -0.322 \\
\hline MD9 & 0.864 & 1.654 & -0.525 \\
\hline MD6 & 0.268 & 0.806 & -0.354 \\
\hline MD7 & -0.506 & 1.393 & 0.458 \\
\hline GRAN & 1.117 & 1.130 & 0.211 \\
\hline VES12 & 0.854 & 1.773 & 0.189 \\
\hline ECL1 & 0.188 & 1.067 & -0.379 \\
\hline ECL2 & 0.036 & 1.248 & -0.333 \\
\hline ECL3 & 0.491 & 1.098 & -0.189 \\
\hline VES3 & 0.910 & 1.303 & 0.240 \\
\hline LANG & -5.639 & -1.236 & 0.387 \\
\hline ERNO & 0.143 & 0.207 & -0.423 \\
\hline MDTH & 0.516 & -0.866 & 0.059 \\
\hline GLAD & 0.621 & 0.115 & -0.734 \\
\hline PREST & 1.084 & -1.262 & -1.015 \\
\hline WING & -1.251 & 1.959 & 1.117 \\
\hline MCGLA & 0.554 & 0.024 & -0.656 \\
\hline COALW & -0.636 & 1.284 & 0.660 \\
\hline SALT & 2.316 & -1.661 & -0.059 \\
\hline О34B & 1.519 & 0.015 & -0.927 \\
\hline ERSO & -0.190 & -0.295 & 0.143 \\
\hline PROS & -1.087 & 0.929 & -1.034 \\
\hline BACK & -0.595 & 0.578 & -0.810 \\
\hline CORE & -8.358 & -5.397 & -0.692 \\
\hline NORW & 0.492 & 0.910 & -0.584 \\
\hline AFAL & 0.271 & -0.452 & 1.311 \\
\hline CONV & -6.780 & 0.315 & -0.427 \\
\hline CHER & 1.241 & -2.578 & 1.077 \\
\hline 5ST & -1.419 & -0.115 & -0.658 \\
\hline $\mathrm{RICH}$ & -7.481 & -2.355 & -0.425 \\
\hline ISAB & 0.951 & -2.845 & 0.108 \\
\hline CLYD & -11.140 & -0.964 & 3.093 \\
\hline
\end{tabular}

Table 7: Principal component scores for each sample on PC1, PC2, and PC3. 
$\mathrm{pH}$ and alkalinity, and high negative loadings from constituents of acidic, un-flooded mine water environments, i.e. $\mathrm{Fe}^{3+}$ and $\mathrm{Al}$. PC3 has high positive loadings only for barium.

\subsubsection{Cluster analysis}

Hierarchical agglomerative cluster analysis (R Core Team, 2012) was conducted on a standardized dataset including $\mathrm{pH}$, pe, alkalinity, $\mathrm{Fe}^{2+}, \mathrm{Fe}^{3+}, \mathrm{Al}, \mathrm{Mn}, \mathrm{Na}, \mathrm{K}, \mathrm{Ca}, \mathrm{Mg}, \mathrm{Ba}, \mathrm{Sr}, \mathrm{SO}_{4}$, $\mathrm{Br}$, and $\mathrm{Cl}$. Ward's linkage method (Ward, 1963) was utilized to minimize within-cluster variance. Euclidean distance was the metric by which clusters were merged. Results are shown in Figure 17-22 and Tables 8-10.

Seven clusters are apparent in the results (Figure 17). Cluster 7 contains only Smith 06b and this sample is therefore considered an outlier. The six remaining clusters fall into two major categories; clusters 1, 2, 5 and 6 are alkaline; clusters 3 and 4 are acidic. Both of these have several sub-categories, based on constituents of total dissolved solids (TDS) estimated from field specific conductance. Conductivities for cluster centroids ranged from $1614 \mu \mathrm{S} / \mathrm{cm}$ to 7952 $\mu \mathrm{S} / \mathrm{cm}$ (Table 8). The six retained clusters display the following characteristics (Table 9):

(C1) alkaline, low TDS, elevated Ba and Sr concentrations,

(C2) alkaline, moderate TDS, elevated $\mathrm{Ba}$ and $\mathrm{Br}$ concentrations,

(C3) acidic, high TDS, elevated Al concentrations,

(C4) acidic, low TDS, elevated $\mathrm{Cl}$ concentrations,

(C5) alkaline, moderate TDS, elevated $\mathrm{Cl}$ concentrations, and

(C6) alkaline, high TDS.

Within the alkaline clusters, one cluster shows low TDS, one high TDS, and the remaining two moderate TDS plus additional diagnostic constituents. The two acidic clusters are distinguished 


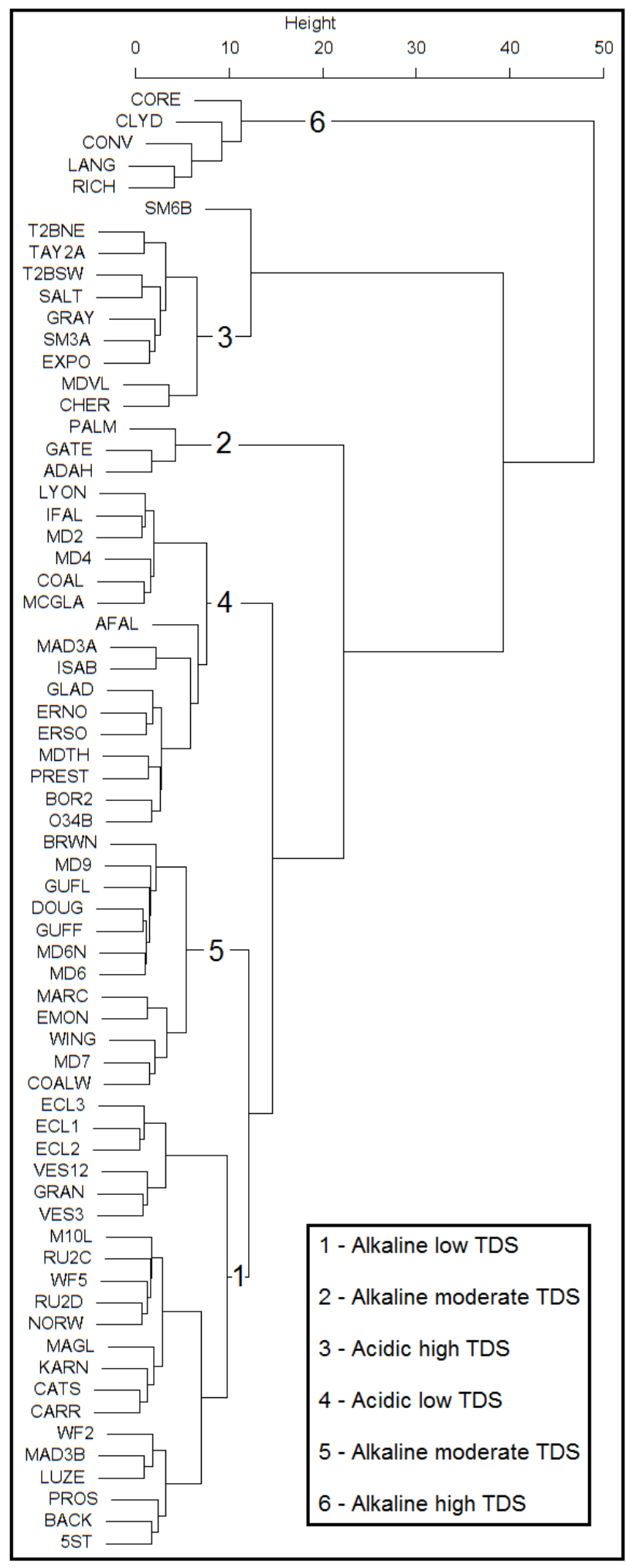

Figure 17: Results of agglomerative hierarchal cluster analysis of standardized chemical data, using Ward's linkage method and Euclidean distance. 


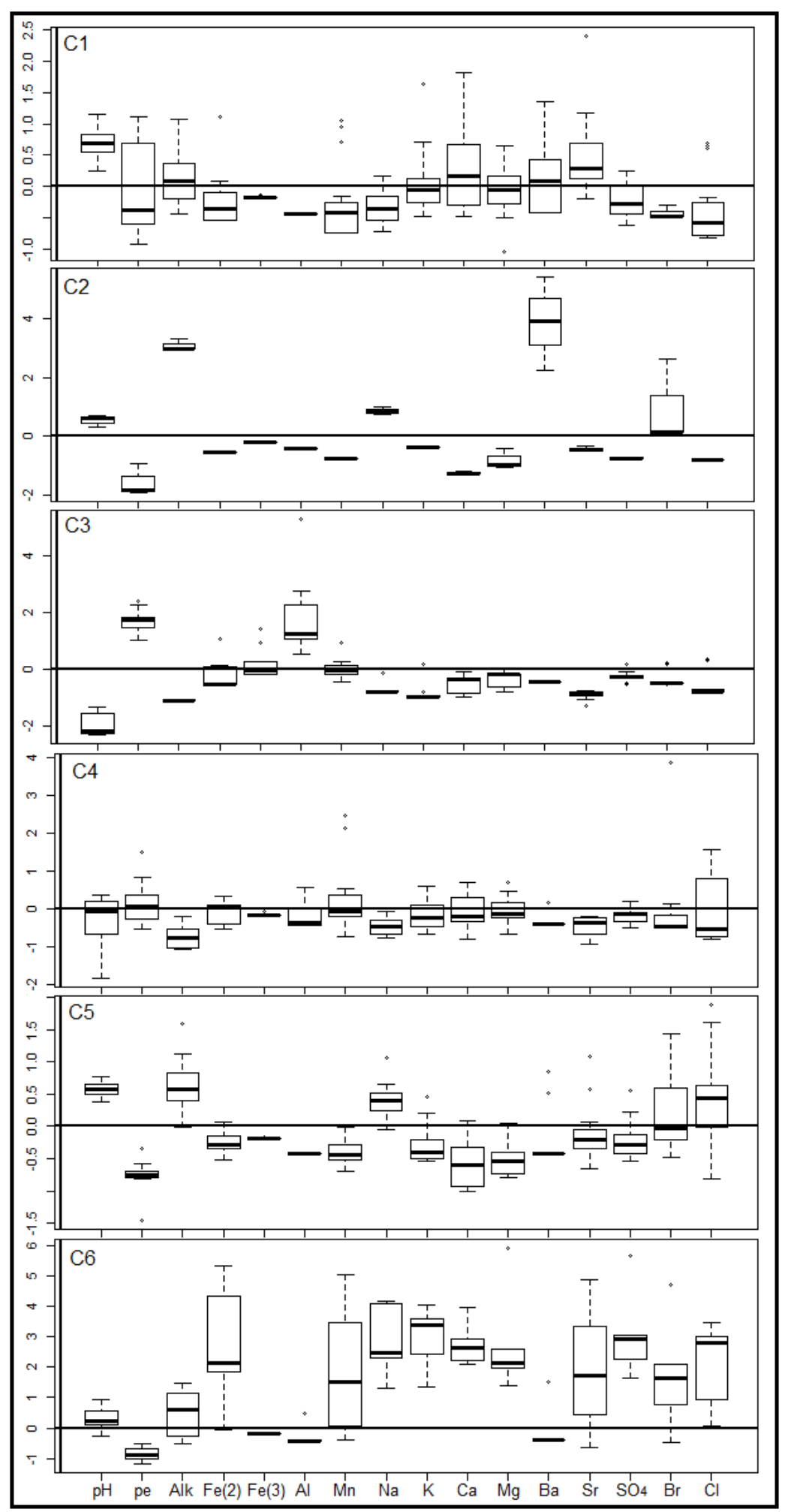

Figure 18: Results of cluster analysis presented as standardized chemical data. Horizontal line represents cluster mean for each parameter. 


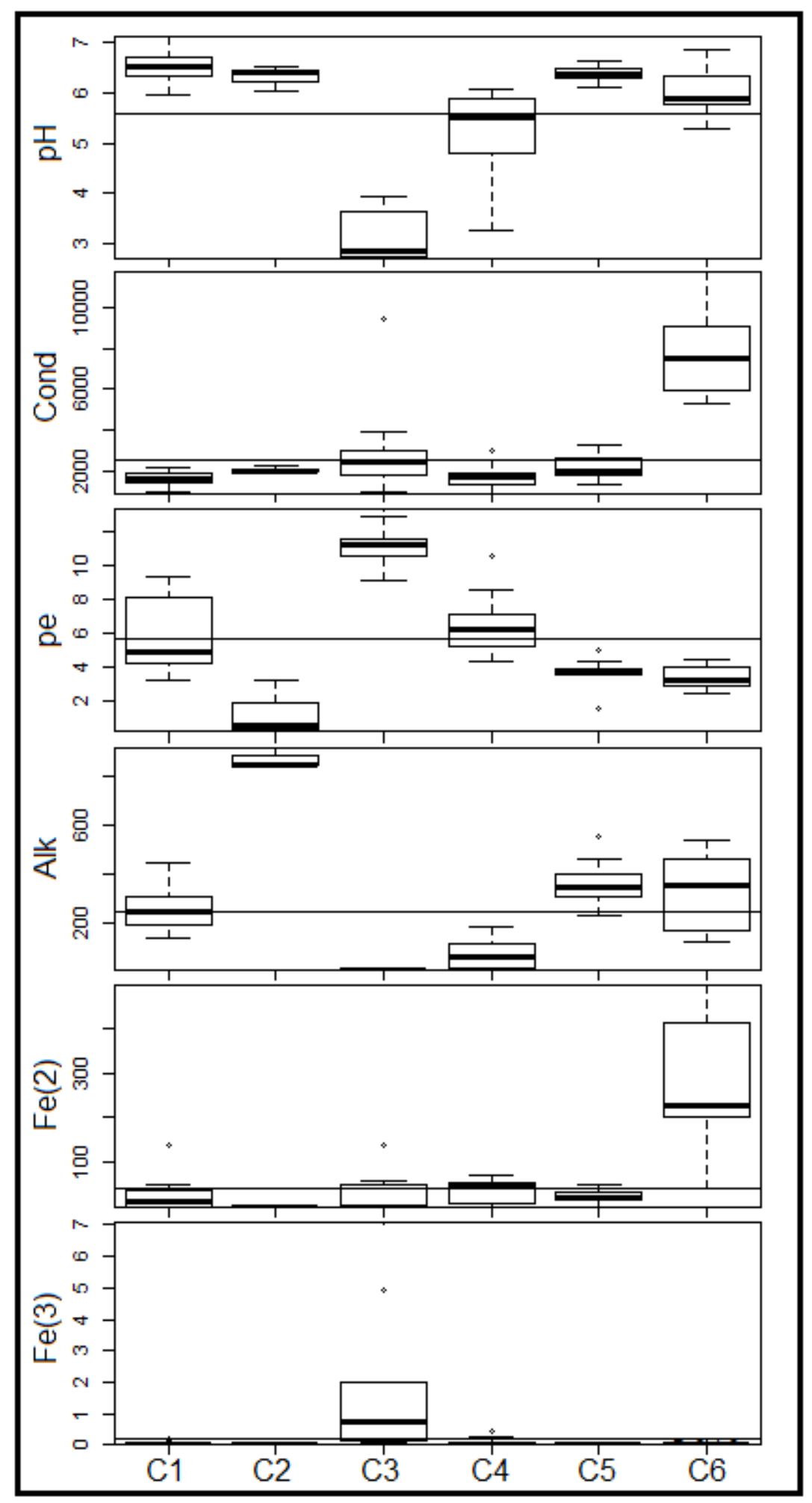

Figure 19: Results of cluster analysis presented as non-standardized chemical data. Horizontal line represents universal mean for each parameter. 


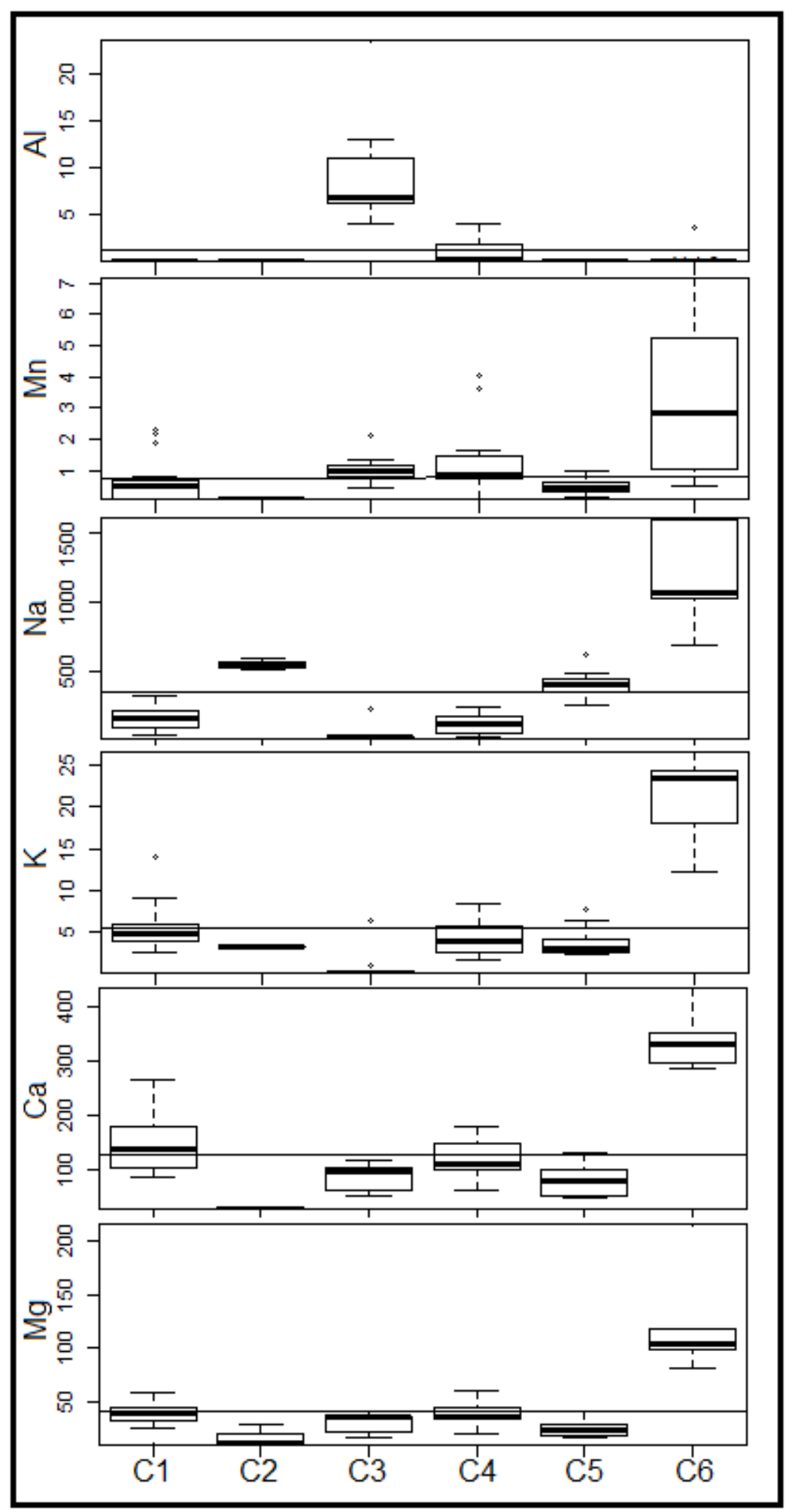

Figure 20: Results of cluster analysis presented as non-standardized chemical data. Horizontal line represents universal mean for each parameter. 


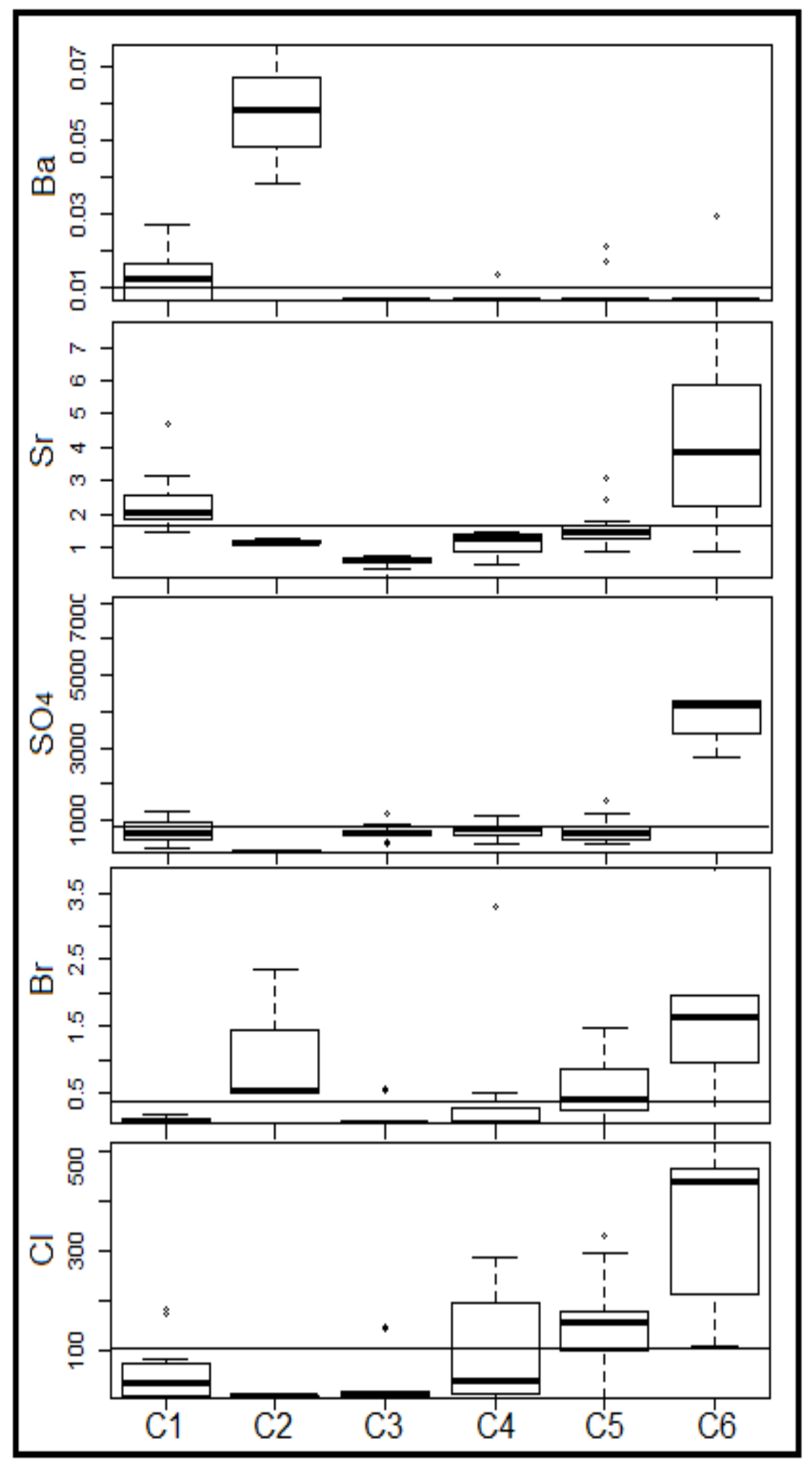

Figure 21: Results of cluster analysis presented as non-standardized chemical data. Horizontal line represents universal mean for each parameter. 


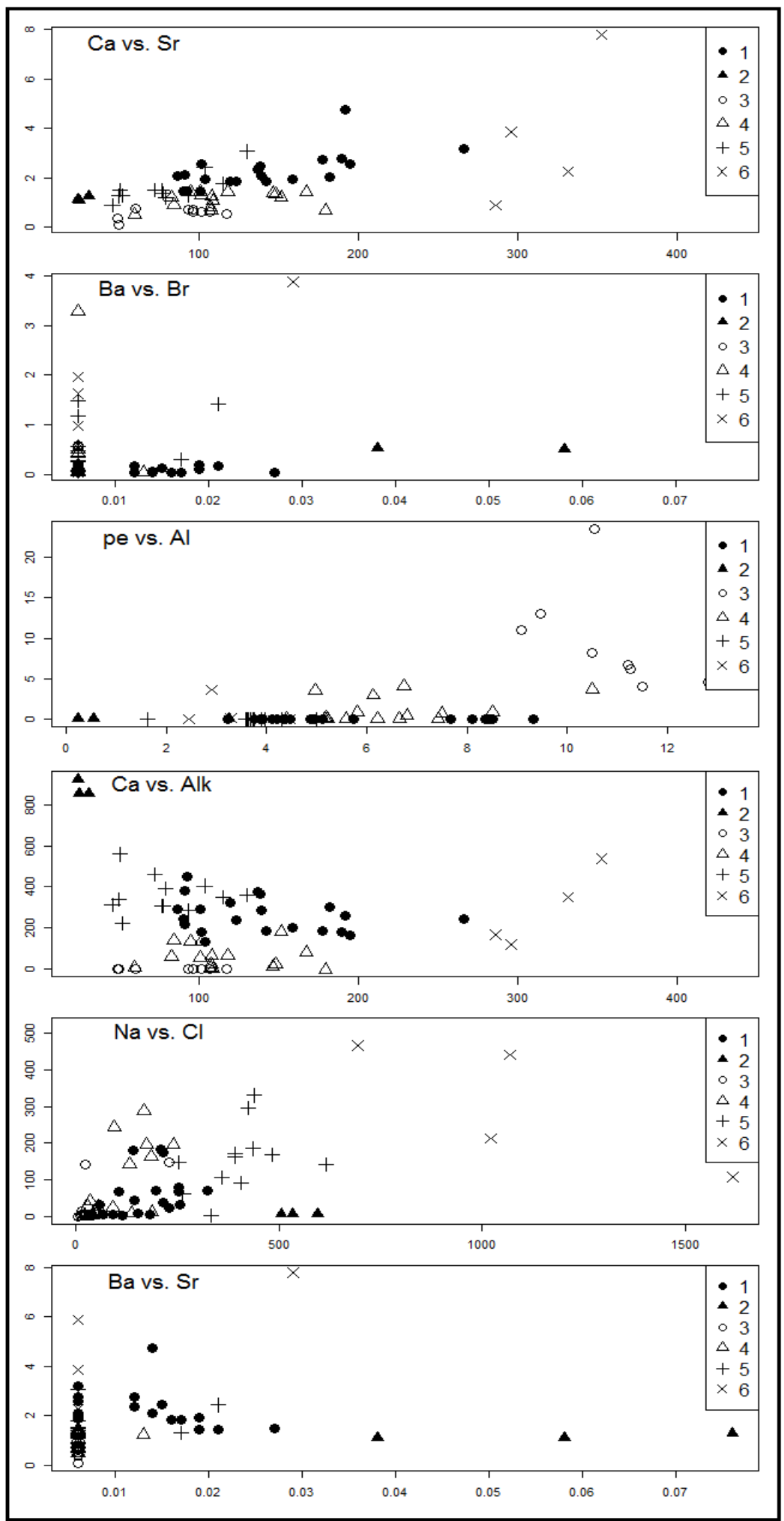

Figure 22: Results of cluster analysis presented as biplots of non-standardized data. Selected parameters represent dominant relationships per cluster. 


\begin{tabular}{|c|c|c|c|c|c|c|c|c|c|c|c|c|c|c|c|c|}
\hline & $\mathrm{pH}$ & Cond & pe & Alk & $\mathrm{Fe}$ & Al & $M n$ & $\mathrm{Na}$ & $K$ & $\mathrm{Ca}$ & $\mathrm{Mg}$ & $\mathrm{Ba}$ & $\mathrm{Sr}$ & $\mathrm{SO} 4$ & $\mathrm{Br}$ & $\mathrm{Cl}$ \\
\hline 1 & 6.53 & 1614 & 5.7 & 263 & 23.5 & 0.05 & 0.59 & 157 & 5.29 & 138.8 & 38.3 & 0.012 & 2.27 & 673 & 0.093 & 52.6 \\
\hline 2 & 6.32 & 2038 & 1.3 & 876 & 0.8 & 0.05 & 0.05 & 544 & 3.19 & 26.5 & 16.1 & 0.057 & 1.17 & 128 & 1.135 & 6.1 \\
\hline 3 & 3.12 & 3044 & 11.1 & 1 & 31.7 & 9.38 & 1.02 & 40 & 0.90 & 85.5 & 30.0 & 0.006 & 0.57 & 671 & 0.174 & 36.8 \\
\hline 4 & 5.25 & 1690 & 6.4 & 63 & 36.4 & 1.11 & 1.24 & 112 & 4.37 & 116.6 & 39.0 & 0.006 & 1.14 & 726 & 0.334 & 105.2 \\
\hline 5 & 6.37 & 2160 & 3.7 & 359 & 24.1 & 0.05 & 0.47 & 399 & 3.75 & 78.7 & 24.7 & 0.008 & 1.59 & 706 & 0.569 & 155.4 \\
\hline 6 & 6.03 & 7952 & 3.4 & 328 & 273.7 & 0.79 & 3.35 & 1199 & 20.96 & 340.2 & 123.7 & 0.011 & 4.13 & 4357 & 1.698 & 349.5 \\
\hline
\end{tabular}

Table 8: Cluster averages. $\mathrm{pH}$ is stated as standard units, specific conductance as $\mu \mathrm{S} / \mathrm{cm}$, alkalinity as $\mathrm{mg} / \mathrm{L}$ as $\mathrm{CaCO}_{3}$, and chemical data as $\mathrm{mg} / \mathrm{L}$. 


\begin{tabular}{|c|c|c|c|c|c|}
\hline 1 & 2 & 3 & 4 & 5 & 6 \\
\hline $\begin{array}{c}\text { 5th Street } \\
\text { Backyard } \\
\text { Carroll } \\
\text { Catsburg } \\
\text { Eclipse1 } \\
\text { Eclipse2 } \\
\text { Eclipse3 } \\
\text { Granville Hollow } \\
\text { Karen } \\
\text { Luzerne } \\
\text { Maiden 3B } \\
\text { Maple Glenn } \\
\text { MD10 Lower } \\
\text { Norway } \\
\text { Prospect } \\
\text { Ruby 2c } \\
\text { Ruby 2d } \\
\text { Vesta \#1 \& \#2 } \\
\text { Vesta \#3 } \\
\text { West Fork } 2 \\
\text { West Fork } 5\end{array}$ & $\begin{array}{l}\text { Adah } \\
\text { Gates } \\
\text { Palmer }\end{array}$ & \begin{tabular}{|c|} 
Cherry Run \\
Export \\
Grays Landing \\
Maidsville \\
Saltwell \\
Smith 03a \\
Taylorstown 2A \\
Taylorstown 2B NE \\
Taylorstown 2B SW
\end{tabular} & $\begin{array}{l}\text { Aluminum Falls } \\
\text { Borland } \\
\text { Coal Run } \\
\text { Erie North } \\
\text { Erie South } \\
\text { Gladden } \\
\text { Iron Falls } \\
\text { Isabella } \\
\text { Lyons Run } \\
\text { Maiden 3A } \\
\text { McGlaughlin Run } \\
\text { MD1000gpm } \\
\text { MD2 } \\
\text { MD4 } \\
\text { Owens 34b } \\
\text { Presto-Sygan }\end{array}$ & \begin{tabular}{|} 
Brownsville \\
Coal Run West \\
Douglas Run \\
East Monongahela \\
Guffey \\
Guffey Lower \\
Marchand \\
MD6 \\
MD6 West \\
MD7 \\
MD9 \\
Wingfield Pines
\end{tabular} & $\begin{array}{c}\text { Clyde } \\
\text { Convent } \\
\text { Core Pump } \\
\text { Langeloth } \\
\text { Richland }\end{array}$ \\
\hline
\end{tabular}

Table 9: Mine discharges from target population arranged by results of cluster analysis. 


\begin{tabular}{c|ccccc}
\hline \hline Cluster & pH & TDS & Major TDS & Unique TDS & \# in Cluster \\
\hline 1 & alkaline & low & $\mathrm{Alk}, \mathrm{SO}_{4}$ & $\mathrm{Ba}, \mathrm{Sr}$ & 21 \\
2 & alkaline & moderate & $\mathrm{Alk}, \mathrm{Na}$ & $\mathrm{Ba}, \mathrm{Br}$ & 3 \\
3 & acidic & high & $\mathrm{SO}_{4}, \mathrm{Ca}$ & $\mathrm{Al}$ & 9 \\
4 & acidic & low & $\mathrm{SO}_{4}, \mathrm{Ca}$ & $\mathrm{Cl}$ & 16 \\
5 & alkaline & moderate & $\mathrm{SO}_{4}, \mathrm{Na}$ & $\mathrm{Cl}$ & 12 \\
6 & alkaline & high & $\mathrm{SO}_{4}, \mathrm{Na}$ & - & 5 \\
\hline \hline
\end{tabular}

Table 10: Diagnostic properties influencing cluster partitioning. 
by magnitude of TDS. The major constituent of the acidic high-TDS cluster is aluminum. The other acidic cluster lacks TDS but shows elevated chloride (Figure 18-22).

Large between-group variance is displayed by alkalinity, $\mathrm{Fe}, \mathrm{Na}, \mathrm{Ca}, \mathrm{SO}_{4}$, and $\mathrm{Cl}$ (Figure 18-21). Iron and sulfate are similar in five of the clusters but much higher in concentration in the alkaline high TDS cluster. Al is similar in five of the clusters but much higher in concentration in the acidic high TDS cluster. Alkalinity, $\mathrm{Na}, \mathrm{Ca}$, and $\mathrm{Cl}$ vary between each of the six clusters (Figures 18-21).

\subsubsection{Spatial analysis}

Cluster spatial distribution shows strong trends (Figure 23). Cluster 1 observations occur in Harrison County, WV, and California, PA. Cluster 2 observations occur in and around Adah, PA, on the east side of the Monongahela River near Uniontown. Cluster 3 observations occur mainly near Morgantown, WV. Cluster 4 and 5 observations occur mainly in the northern coal basin. Cluster 6 observations are widely distributed with little trend.

High specific conductance samples are concentrated within the alkaline high TDS cluster and are scattered throughout the study area. Many high chloride samples also occur in the north of the study area. Samples displaying elevated bromide occur sparsely scattered throughout the study area. Samples displaying elevated barium are isolated to several samples in close proximity to Adah, PA. 


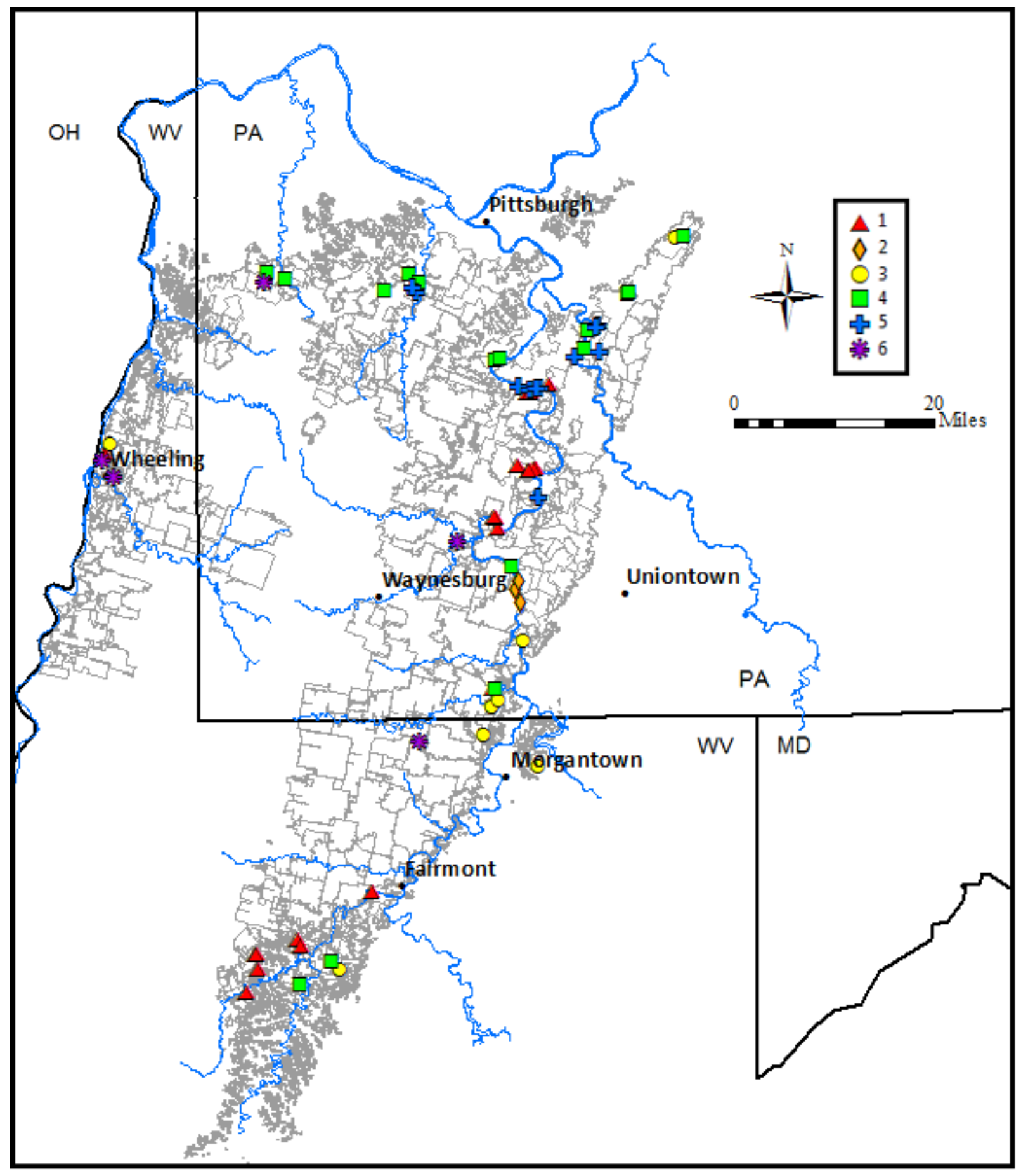

Figure 23: Spatial distribution of cluster analysis results. 


\section{DISCUSSION OF RESULTS}

\subsection{Mine water settings}

\subsubsection{Principal component 1}

Principal component 1 (PC1) is interpreted to represent an inverse scaling of salinity in Pittsburgh mine water. Five saline waters are high negative scores, but nearly all other waters are low scores (positive or negative). So, although PC1 represents salinity, it is dominated by only a few unusual, very saline samples.

Samples scoring negatively on $\mathrm{PC} 1$ have high concentrations of $\mathrm{Na}, \mathrm{Cl}, \mathrm{Br}$, and $\mathrm{Sr}$. The samples Clyde, Convent, Richland, Langlothe, and core score very negatively on PC1 (Figure 13-14). The average specific conductance for these four is $7952 \mu \mathrm{S} / \mathrm{cm}$. In addition, other solutes are high including $\mathrm{Na}(1199 \mathrm{mg} / \mathrm{L}), \mathrm{Cl}$ (350 mg/L), $\mathrm{Br}(1.69 \mathrm{mg} / \mathrm{L})$, and $\mathrm{Sr}(4.13 \mathrm{mg} / \mathrm{L})$. High values/concentrations of $\mathrm{pH}$, alkalinity, $\mathrm{Ba}, \mathrm{Ca}, \mathrm{Mg}, \mathrm{Fe}^{2+}, \mathrm{SO}_{4}$, and $\mathrm{Mn}$ also characterize these samples. Additional samples score negatively on PC1 due to moderate concentrations of the components $\mathrm{pH}$, alkalinity, $\mathrm{Ba}, \mathrm{Ca}, \mathrm{Mg}, \mathrm{Fe}^{2+}, \mathrm{SO}_{4}$, and $\mathrm{Mn}$, but not to the magnitude of the few unusual, very saline samples.

Samples scoring positively on PC1 have low concentrations of $\mathrm{Na}, \mathrm{Cl}, \mathrm{Br}$, and Sr. Such samples include Borland, Saltwell, Taylorstown 2A and 2B, Grays Landing, Export, and Maidsville (Figure 13-14). The average specific conductance of these is $2088 \mu \mathrm{S} / \mathrm{cm}$, with Na (18.1 mg/L), Cl (23.6 mg/L), Br (0.12 mg/L), and $\mathrm{Sr}(0.54 \mathrm{mg} / \mathrm{L})$, which are considerably lower than for samples scoring negatively on PC1. Samples scoring positively on PC1 are low in salinity, but have elevated concentrations of $\mathrm{Fe}^{3+}, \mathrm{Al}$, and electrode potential. 
Salinity of mine water is interpreted to be influenced by factors including duration postclosure, degree of flushing of juvenile mine water, and contamination by formation brines. Therefore, samples with very negative scores on PC1 may have been influenced by one or more of these factors.

\subsubsection{Principal component 2}

Principal component 2 (PC2) is interpreted to reflect inverse scaling of acidity of Pittsburgh mine water. The samples Maidsville, Taylorstown 2A and 2B, Smith 03A and 06B, Grays Landing, Export, Saltwell, Cherry Run, Isabella, Presto-Sygan, and Maiden 3A score negatively on PC2 (Figure 13-14) with average $\mathrm{pH} 3.4$ and alkalinity $1.4 \mathrm{mg} / \mathrm{L}$ as $\mathrm{CaCO}_{3}$. Samples scoring negatively on PC2 contain elevated concentrations of $\mathrm{Fe}^{3+}, \mathrm{Al}$, and electrode

potential. The components $\mathrm{Ca}, \mathrm{Mg}, \mathrm{Fe}^{2+}, \mathrm{SO}_{4}$, and Mn negatively load on PC2 (Figure 13-14). Samples scoring positively on PC2 are, conversely, alkaline. The samples Palmer, Adah, and Gates, all along the east bank of the Monongahela from deep flowing wells in the deepest part of mine pools, score positively on PC2 (Figure 13-14) with average pH 6.3 and alkalinity $876 \mathrm{mg} / \mathrm{L}$ as $\mathrm{CaCO}_{3}$ ). Samples scoring positively on PC2 contain elevated $\mathrm{pH}, \mathrm{Alk}, \mathrm{Ba}, \mathrm{Sr}, \mathrm{Br}$, and $\mathrm{Na}$ and are often low in Fe. The lower oxygen availability in below-drainage flooded underground mines decreases the dissolution of iron sulfide minerals and iron hydrolysis so that the acidity that does evolve is effectively buffered by calcite dissolution.

As with PC1, additional samples score both positively and negatively on PC2, but not to the magnitude of the few unusual, highly acidic or alkaline samples. PC2 is influenced by mine setting. The acidic samples scoring positively on PC2 discharge from the shallow partiallyflooded to un-flooded eastern margin of the coal basin. The alkaline samples scoring negatively 
on PC2 discharge from deep fully flooded mines. The bimodal, negatively-skewed distribution for $\mathrm{pH}$ underscores the finding that a small portion of the acidic mine waters sampled lie above drainage. These oxygen-rich, aluminum-rich low $\mathrm{pH}$ waters explain the negative correlation between $\mathrm{pH}$ with both $\mathrm{Al}$ and redox potential.

\subsubsection{Principal component 3}

Principal component 3 (PC3) elevated Ba concentrations in Pittsburgh mine waters. Four Ba-enriched waters are high positive scores, but nearly all other waters are low scores (positive or negative). So, although PC3 represents a Ba-enriched population, Pittsburgh mine water chemistry is influenced by only a few unusual, Ba-enriched samples.

Samples scoring negatively on PC3 contain extremely low or undetectable concentrations of Ba. The samples West Fork 2, Ruby 2C and 2D, Prospect, Maple Glenn, Maiden 3B, and Presto-Sygan score negatively on PC3 (Figure 15-16) and have average Ba concentration below detection limit $(0.012 \mathrm{mg} / \mathrm{L})$. Elevated $\mathrm{pH}$ loads negatively on PC3 indicating that while Ba is more commonly present in alkaline waters; constituents other than Ba more heavily influence alkaline waters.

Samples scoring positively on PC3 contain relatively high concentrations of $\mathrm{Ba}$, with moderate concentrations of $\mathrm{Br}, \mathrm{Fe}^{3+}, \mathrm{Al}$, and alkalinity. The samples Palmer, Adah, Gates, and Clyde score positively on PC3 (Figure 15-16) and have average Ba concentrations of 0.050 mg/L and $\mathrm{Br}$ concentrations of $1.82 \mathrm{mg} / \mathrm{L}$. Smith 06B scores positively on PC3 and contributes the covariance of $\mathrm{Fe}^{3+}$ and $\mathrm{Al}$ with other positive PC3 components.

PC3 represents the Ba component of Pittsburgh coal mine discharges. The presence of Ba in both alkaline and acidic samples indicates that both fully flooded and un-flooded mines are 
susceptible to influence of this element. However, positive loadings from saturation and depth on PC3 indicate deep alkaline waters are more likely to show such high concentrations than waters from shallow, un-flooded to partially-flooded mines. Barium is derived by silicate alteration and results from leaching of barite from shale bedrock (Dresel and Rose, 2010). Barite is dissolved during the migration of low sulfate brines through low porosity shale, resulting in elevated $\mathrm{Ba}$ levels in otherwise Ba-deficient brine. Admixture of even small amounts of the shale derived brine with near-surface freshwater can produce barium levels above current limits established by the U.S. Environmental Protection Agency for drinking water (Dresel and Rose, 2010).

\subsubsection{Influences on PCA}

Outliers heavily influence PCA results for this dataset. A small number $(5,3$, and 1 , respectively) of extremely negative scores tend to dominate PC1, PC2, and PC3 (Figure 13-16). The scores influencing PC1 and PC3 contain constituents of salinity that occupy pore spaces in Paleozoic sedimentary rocks. Emplacement in Paleozoic stratigraphy results from the migration of Na-Cl-Br saturated waters without alteration of siliceous or carbonate bedrock (Dresel and Rose, 2010). The constituents $\mathrm{Na}, \mathrm{Ca}, \mathrm{Mg}, \mathrm{Br}, \mathrm{Cl}$, density, and specific conductivity are closely correlated in these brines, while sulfate and carbonate constituents such as $\mathrm{Ba}$ and $\mathrm{Sr}$, respectively, are generally lower and more variable (Dresel and Rose, 2010). The scores influencing PC2 are related to constituents of pyrite and carbonate dissolution.

The majority of waters score near zero and marginally influence eigenvectors PC1, PC2, and PC3. These waters often contain constituents representative of each of the three eigenvectors; for instance, the samples scoring negatively on PC2 also score positively on PC1. 
The interpretation is these samples are acidic and lack salinity. Samples scoring negatively on PC1 and positively on PC3 are saline with high Ba concentrations. Samples not scoring on the salinity eigenvector (PC1) still have minimal concentrations of $\mathrm{Sr}, \mathrm{Cl}, \mathrm{Ba}$, or $\mathrm{Br}$. The presence of other constituents subdues the loadings on PC1 from components of salinity for these samples.

The constituents $\mathrm{Ca}, \mathrm{Mg}, \mathrm{Mn}, \mathrm{Fe}$, and $\mathrm{SO}_{4}$ are ubiquitous in both alkaline and acidic discharges of the Pittsburgh coal. $\mathrm{Fe}$ and $\mathrm{SO}_{4}$ result from pyrite dissolution, and $\mathrm{Ca}, \mathrm{Mg}$, and Mn result from dissolution of carbonate minerals in the Pittsburgh coal overburden. Often, these constituents are present in acidic, alkaline, and saline waters and moderate outlier loadings in PCA.

\subsection{Evolution of Geochemistry}

Over time Pittsburgh mine water from a specific mine changes in chemistry from irondominated and acidic to alkaline or net-alkaline, with or without iron, in below drainage mines. Ubiquitous to the study area are higher concentrations of $\mathrm{Ca}, \mathrm{Na}$, and $\mathrm{SO}_{4}$ than other constituents (Table 10). Pyrite dissolution, widely inferred for mine water of the Pittsburgh coal (Sanchez, 2008), is supported by current PCA results, particularly high negative scores on PC1 and PC2 from samples with high $\mathrm{Fe}$ and $\mathrm{SO}_{4}$, and by strong correlation between $\mathrm{Fe}$ and $\mathrm{SO}_{4}$. However, the signature of pyrite dissolution is being suppressed by the introduction of alkalinity, $\mathrm{Ca}$ and $\mathrm{Na}$, a chemistry of Pittsburgh mine waters that is less well documented.

Sulfate is the most abundant solute in Pittsburgh coal discharges with an average concentration for sixty-eight samples of $923 \mathrm{mg} / \mathrm{L}$. Na follows with average concentration 267 $\mathrm{mg} / \mathrm{L}$, alkalinity with average concentration $226 \mathrm{mg} / \mathrm{L}$ as $\mathrm{CaCO}_{3}$, Ca with average concentration $124 \mathrm{mg} / \mathrm{L}$, chloride with average concentration $100 \mathrm{mg} / \mathrm{L}$, and Fe with average concentration 45 
$\mathrm{mg} / \mathrm{L}$. The sulfate is derived from pyrite dissolution and in some cases converted to dissolved sulfide in deep pools. Alkalinity, $\mathrm{Ca}$, and $\mathrm{Mg}$ result from dissolution of carbonate minerals in the overburden of the Pittsburgh coal. Sodium results from cation exchange on the surface of clays present in overburden. The abundant divalent $\mathrm{Ca}$ introduced by carbonate mineral dissolution replaces monovalent $\mathrm{Na}$ on clay surfaces.

Carbon dioxide partial pressure $\left(\mathrm{pCO}_{2}\right)$ increases with mine pool depth (Figure-31). Clusters C2 and C6 contain deep fully flooded mines discharging from the highest coal bed elevation. The corresponding $\mathrm{pCO}_{2}$ is the highest sampled in the basin with average for $\mathrm{C} 2\left(10^{-}\right.$ $\left.{ }^{0.4} \mathrm{~atm}\right)$ and C6 (10 $\left.0^{-0.7} \mathrm{~atm}\right)$. This is attributed to closed-system behavior created by deep, fully flooded conditions that minimize $\mathrm{CO}_{2}$ escape. A result of this $\mathrm{CO}_{2}$-pressurized condition is that it forces alkalinity higher (Figure 24). C1 and C5 contain partially-flooded mines with un-

flooded headspace over the hydrostatic surface. The corresponding $\mathrm{pCO}_{2}$ average for $\mathrm{C} 1\left(10^{-1.2}\right.$ atm) and $\mathrm{C} 5\left(10^{-0.9} \mathrm{~atm}\right)$ indicate escape of $\mathrm{CO}_{2}$.

\subsection{Spatial analysis}

The six clusters of Table 9 are mainly alkaline with high concentrations of $\mathrm{Ca}, \mathrm{Na}$, and $\mathrm{SO}_{4}$, however, the six clusters show minor but diagnostic differences in specific constituents (mainly $\mathrm{Ba}, \mathrm{Br}, \mathrm{Sr}, \mathrm{Cl}$, and $\mathrm{Al}$; Table 10) and show a coherent spatial distribution (Figure 23). Cluster $1(\mathrm{C} 1)$ samples are alkaline with relatively large concentrations of $\mathrm{Ca}, \mathrm{Ba}$, and $\mathrm{Sr}$. Average $\mathrm{pH}$ is 6.5 , average $\mathrm{Ca}$ is $138 \mathrm{mg} / \mathrm{L}$, average $\mathrm{Ba}$ is $0.012 \mathrm{mg} / \mathrm{L}$, and average $\mathrm{Sr}$ is 2.3 $\mathrm{mg} / \mathrm{L}$. C1 discharges are concentrated around three locations; Harrison County, WV, California, PA, and Luzerne, PA. The relatively low alkalinity of $\mathrm{C} 1$ mine water results from the shallow overburden consisting mainly of pyrite rich shale and sandstone (Cecil, 2012). The carbonate 


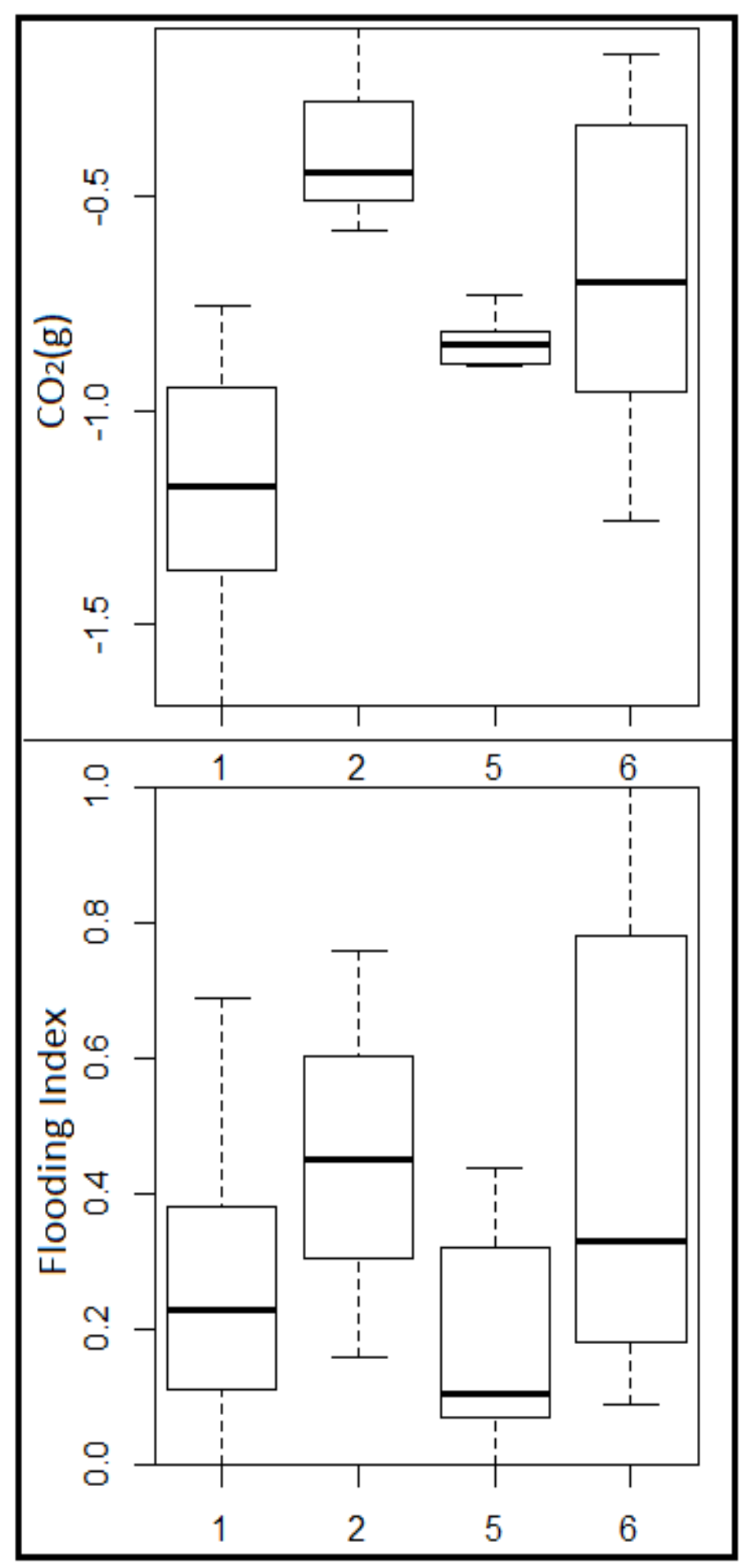

Figure 24: Comparison of $\mathrm{pCO}_{2}$ to mine pool depth. $\mathrm{pCO}_{2}$ displayed as log value along y-axis, depth calculation displayed along y-axis, and respective alkaline mine clusters $(\mathrm{C} 1$, C2, C5, C6) along x-axis. 
overburden is more prevalent further into the coal basin. Contamination by Devonian formation brines is likely the source of the observed $\mathrm{Ba}$ and Sr. Silurian and Pennsylvanian brines are typically Na-Cl-Br, but Devonian brines contain elevated Ba from barite dissolution in siliceous Devonian bedrock, and elevated Sr from celestite dissolution in Devonian carbonates (Dresel and Rose, 2010).

Cluster 2 (C2) samples are alkaline with relatively large concentrations of $\mathrm{Na}, \mathrm{Ba}$ and $\mathrm{Br}$. Average $\mathrm{pH}$ is 6.3 , average alkalinity is $876 \mathrm{mg} / \mathrm{L}$, average $\mathrm{Na}$ is $544.3 \mathrm{mg} / \mathrm{L}$, average Ba is 0.06 $\mathrm{mg} / \mathrm{L}$, and average $\mathrm{Br}$ is $1.1 \mathrm{mg} / \mathrm{L}$. C2 discharges are concentrated around Adah, PA. Alkalinity and $\mathrm{Na}$ constitute the majority of dissolved constituent in C2 samples and are introduced by carbonate mineral dissolution and subsequent cation exchange of $\mathrm{Na}$ with $\mathrm{Ca}$. Alkalinity is maintained at a high concentration by the closed-system dynamics of carbon dioxide dissolution and the associated high $\mathrm{pCO}_{2}$. $\mathrm{Ba}$ and $\mathrm{Br}$ concentrations are relatively high compared to other clusters (Figure 18-21), and indicate mixing of $\mathrm{Na}-\mathrm{Cl}-\mathrm{Br}$ brines occupying pore space of Pennsylvanian bedrock with Ba-rich Devonian brine.

Cluster 3 (C3) samples are acidic with relatively large concentrations of Al. Average pH is 3.1 and average aluminum is $9.4 \mathrm{mg} / \mathrm{L}$. Discharges are concentrated northeast of Morgantown, WV, near the easternmost outcrop of the Pittsburgh coal. The oxygen-rich conditions promote long-term dissolution of iron sulfide minerals, clay minerals, and carbonate minerals as well as precipitation of $\mathrm{Fe}(\mathrm{OH})_{3}$. The acidic conditions maintain the large concentrations of dissolution products. Acidity neutralizes carbonate alkalinity resulting in loss of alkalinity as carbon dioxide. Calculated $\mathrm{pCO}_{2}\left(10^{-0.45} \mathrm{~atm}\right)$ indicates immediate neutralization of carbonate alkalinity. 
Cluster 4 (C4) samples are acidic with relatively large concentrations of Mn and chloride. Average $\mathrm{pH}$ is 5.2 , average $\mathrm{Mn}$ is $1.21 \mathrm{mg} / \mathrm{L}$, and average $\mathrm{Cl}$ is $105.2 \mathrm{mg} / \mathrm{L}$. C4 discharges are concentrated in the northern coal basin of Pennsylvania, with only two samples occurring in West Virginia (Figure 23). Elevated manganese concentrations are supported by dissolution of siderite deposits which contributes iron, alkalinity, and in some cases manganese (Larsen and Mann, 2005). Elevated chloride results from infiltration of $\mathrm{Na}-\mathrm{Cl}-\mathrm{Br}$ rich brines occupying pore space in Pennsylvanian stratigraphy. Deep Silurian brine migrated to Pennsylvanian bedrock during Paleozoic deformation (Dresel and Rose, 2010). The infiltration of these Pennsylvanian brines into mine water potentially results from conventional gas well drilling during the previous century.

Cluster 5 (C5) samples show similarly large concentrations of chloride as C4, but more alkalinity. Average $\mathrm{pH}$ is 6.4 , average alkalinity is $359 \mathrm{mg} / \mathrm{L}$ as $\mathrm{CaCO}_{3}$, and average chloride is $155.4 \mathrm{mg} / \mathrm{L}$. C5 discharges are concentrated in the northern coal basin of Pennsylvania. C5 unique characteristics are elevated alkalinity, $\mathrm{Na}, \mathrm{Cl}$, and $\mathrm{Br}$ concentrations; and depleted $\mathrm{Fe}$ and $\mathrm{Al}$ concentrations. C5 mines are commonly flooded and oxygen depleted, reducing mineral dissolution and acidity resulting in the observed low $\mathrm{Fe}$ and $\mathrm{Al}$ concentrations. This $\mathrm{Na}-\mathrm{Cl}-\mathrm{Br}$ chemistry indicates infiltration of Paleozoic brine sans influence from $\mathrm{Ba}$ and $\mathrm{Sr}$ rich Devonian shale. As with $\mathrm{C} 4$, the brine contamination potentially results from conventional gas well drilling during the previous century as opposed to recent resource extraction in Devonian bedrock.

Cluster 6 (C6) samples are alkaline with relatively large concentrations of all constituents. e.g. higher salinity. Average $\mathrm{pH}$ is 6.0 and average concentrations for all 
parameters exceed those in C1-C5. C6 discharges are geographically scattered throughout the study area. Elevated chemical constituents are $\mathrm{Fe}, \mathrm{Mn}, \mathrm{Na}, \mathrm{K}, \mathrm{Ca}, \mathrm{Mg}, \mathrm{Sr}, \mathrm{SO}_{4}, \mathrm{Br}$, and $\mathrm{Cl}$. These samples are from mines that are relatively recently closed (since 1977). There is also the potential of some of these waters to have undergone contamination by deep formation waters. Negative scores on PC1 are samples with membership in C6. 


\section{CONCLUSIONS}

All discharges in the studied subcrop of the Pittsburgh coal contain products of pyrite dissolution $\left(\mathrm{Fe}, \mathrm{SO}_{4}\right)$. Fe varies from below detection limits in waters of oxygen depleted mines and pyrite depleted mines, to concentrated in juvenile and acidic mine waters. Sulfate is concentrated basin-wide. The majority of discharges are alkaline with products of carbonate dissolution $(\mathrm{Ca}, \mathrm{Mg}) . \mathrm{Ca}$ and $\mathrm{Mg}$ are ubiquitous in both acidic and alkaline discharges with correlation $(\mathrm{r}=0.77)$ indicative of dissolution from a similar source, though a portion of the $\mathrm{Mg}$ may be derived from clay dissolution. A small number of Na-enriched discharges occur in the presence of alkalinity. The smaller radii and divalent charge of $\mathrm{Ca}$ ion, introduced by carbonate dissolution, exchange monovalent $\mathrm{Na}$ from clay surfaces.

A small number of discharges in this data set classify into subsets ranging from highly saline, to highly acidic, to highly alkaline, to Ba enriched, as indicated by the results of PCA. The results are weighted by non-normal skewed distributions with outliers occurring for several parameters in several samples. The majority of samples score near zero on PCA indicating that only a small number of discharges fall into an extremely saline, acidic, alkaline or Ba influenced classifications.

Cluster analysis reveals two major categories, acidic and alkaline. The categories are subdivided by magnitude and composition of TDS. The diagnostic constituents are mainly brine related and observed in alkaline mine waters $(\mathrm{Ba}, \mathrm{Sr}, \mathrm{Na}, \mathrm{Cl}, \mathrm{Br})$. A smaller number of constituents from acidic water influence cluster analysis results (Al, Mn). Two acidic discharges did, however, indicate influences from brine (Br). The large number of clusters (6) exceeds 
previous results of cluster analysis of mine water geochemistry (Stiles, 2004). A spatial trend was observed as CA results were concentrated around specific cities and regions.

Carbon dioxide partial pressure displays a direct relationship with magnitude of flooding. Dissolution of carbonate by acidic mine water under closed system conditions introduces $\mathrm{CO}_{2}$. Increased flooding index of a mine, indicating greater saturation and a larger mine pool, corresponds to increased $\mathrm{pCO}_{2}$. The $\mathrm{pCO}_{2}$ calculated for mines with high flooding index are substantially larger than atmospheric $\mathrm{CO}_{2}$. The increased $\mathrm{pCO}_{2}$ under closed system conditions drives alkalinity in these mines close to $1000 \mathrm{mg} / \mathrm{L}$ as $\mathrm{CaCO}_{3}$.

The observed alkalinity and Na rich discharges from this subcrop of the Pittsburgh coal differ from the oxygen rich, acidic, metals-enriched chemistry typically associated with bituminous coal mining. The presence of $\mathrm{Na}$ without $\mathrm{Cl}$ indicates cationic exchange on clay surfaces as the Na source; as opposed to halite dissolution from evaporate brines. The presence of alkaline overburden both mitigates acid production and provides the Ca necessary for surface exchange with Na. The extreme saline discharges observed are indicative of conventional resource extraction in the basin during the previous half century and more recent unconventional resource extraction, as well as infiltration from shallow Pennsylvanian brines. Brine constituents were emplaced in pore space of Pennsylvanian bedrock by fluid migration during tectonic deformation associated with the Appalachian orogeny (Dresel and Rose, 2010). 


\section{REFERENCES CITED}

Arndt, H.H., Averitt, Paul, Dowd, James, Frendzel, D.J., and Gall, P.A. 1968. Coal, in Mineral resources of the Appalachian region: U.S. Geol. Survey Prof. Paper 580, pp. 102-133.

Bigham, J. M., and Nordstrom, D. K., 2000, Iron and aluminum hydroxysulfate minerals from acid sulfate waters, In Jambor, J. L., Alpers, C. N., and Nordstrom, D. K., (eds.), Sulfate minerals, crystallography, geochemistry and environmental significance: Mineralogical Society of America Reviews in Mineralogy and Geochemistry, v. 40, p. 351-403.

Bigham, J.M., Schwertmann, U., Traina, S.J., Winland R.L., and Wolf, M. 1996. Schwertmannite and the chemical modeling of iron in acid sulfate waters. Journal of Geochimica et Cosmochimica Acta. Vol. 60, No. 12, pp. 2111-2121.

Booth, C.J. 2002. The effects of longwall mining on overlying aquifers, In P.L. Younger and N.S. Robins, eds., Mine water hydrogeology and geochemistry: Geologic Society (London) Special Publication 198, pp. 17-45.

Booth, C.J., Spande, E.D., Pattee, C.T., Miller, J.D., and Bertsch, L.P. 1998. Positive and negative impacts of longwall mining on a sandstone aquifer. Journal of Environmental Geology, Vol. 34, No. 213, pp. 223-233.

Capo, R.C., Winters, W.R., Weaver, T.J., Stafford, S.L., Hedin, R.S., and Stewart, B.W. 2001. Hydrogeologic and geochemical evolution of deep mine discharges, Irwin Syncline, Pennsylvania. In Proceedings, West Virginia Mine Drainage Task Force Symposium, Morgantown, WV, pp. 1-10.

Cecil, C.B., Brezinski, D.K., Dulong, F. 2012. The Paleozoic record of changes in global climate and sea level: central Appalachian basin. Fieldtrip, Chapter 3, pp. 77-135.

Cravotta, C.A, and Kirby, C.S. 2004. Acidity and alkalinity in mine drainage: practical considerations. In Proceedings, National Meeting of the American Society of Mining and Reclamation, Morgantown, WV.

Demchak, J., Skousen, J., and McDonald L.M. 2004. Longevity of acid discharges from underground mines located above the regional water table. Journal of Environmental Quality, Vol. 33, pp. 656-658.

Donovan J.J., and Fletcher, J., 1999. Hydrogeological and geochemical response to mine flooding in the Pittsburgh coal basin, southern Monongahela River basin. Project WV132 Report to the U.S. Environmental Protection Agency, 47p. 
Donovan, J.J., and Leavitt, B.R. 2004. The future of mine-water discharges from underground coal mines of the Pittsburgh Coal Basin, WV-PA. In Proceedings, National Meeting of the American Society of Mining and Reclamation, Morgantown, WV, pp. 518-528.

Dresel, P.E., Rose, A.W., 2010. Chemistry and origin of oil and gas well brines in western pennsylvania. Pennsylvania Geologic Survey, 4th ser., open-file report OFOG 10-01.0, Portable Document Format (PDF).

Equeenuddin, S.M., Tripathy, S., Sahoo, P.K., and Panigrahi, M.K. 2010. Hydrogeochemical characteristics of acid mine drainage and water pollution at Makum Coalfield, Indiana. Journal of Geochemical Exploration, Vol. 105, pp. 75-82.

Fenneman, N. M. 1938. Physiography of the eastern United States. New York: McGraw-Hill. $714 \mathrm{p}$.

Grubbs, F. 1969. Procedures for detecting outlying observations in samples. Journal of Technometrics. Vol. 11, No. 1, pp. 1-21.

Kaiser, H.F. 1960. The application of electronic computers to factor analysis. Journal of Educational and Physhological Measurement. Vol. 20, pp. 141-151.

Lambert, D.C, McDonough, K.M., and Dzombak, D.A. 2004. Long-term changes in quality of discharge water from abandoned underground coal mines in the Uniontown syncline, Fayette County, PA, USA. Journal of Water Research, Vol. 38, pp. 277-288.

Larsen, D., and Mann, R. 2005. Origin of high manganese concentrations in coal mine drainage, eastern Tennessee. Journal of Geochemical Exploration. Vol. 86, pp. 143-163.

Leavitt, B.R., Donovan, J.J., Morris, A.J., and Werner, E. 2003. Modeling mine flooding in the Pittsburgh coal basin, USA. In Proceedings, $6^{\text {th }}$ International Conference on Acid Rock Drainage, Cairns, QLD, pp. 1065-1071.

Mack, B., McDonald, L.M., and Skousen, J. 2010. Acidity decay of above-drainage underground mines in West Virginia. Journal of Environmental Quality, Vol. 39, pp. 1043-1050.

McCoy, K.J. 2002. Estimation of vertical infiltration into deep Pittsburgh coal mines of WVPA: A fluid mass balance approach. Master's thesis, West Virginia University: U.S.A. 
McCoy, K.J., Donovan, J.J., and Leavitt, B.R. 2006. Horizontal hydraulic conductivity estimates for intact coal barriers between closed underground mines. Journal of Environmental \& Engineering Geoscience, Vol. 12, No. 3, pp. 273-282.

McDonough, K.M., Lambert, D.C., Mugunthan, P., and Dzombak, D.A. 2005. Hydrologic and geochemical factors governing chemical evolution of discharges from an abandoned, flooded, underground coal mine network. Journal of Environmental Engineering, April, pp. 643-650.

Mentz JW, and Wang JB. 1975. Up-dip versus down-dip mining: an evaluation. EPA-670/2-75047, National Environmental Research Center, Office of Research and Development, United States Environmental Protection Agency, Cincinnati, $\mathrm{OH}$.

Miller, R.L., Hadley, J.B., and Cox, D.P. 1968. General geology. In: Mineral Resources of the Appalachian Region. USGS and USBM, USGS Professional Paper 580, pp. 55-80.

Morris, A.J., Donovan, J.J., and Thies, J.E. 2008. Reconnaissance spatial analysis of the hydrogeology of closed underground coal mines. Journal of Environmental Geosciences, Vol. 15, No. 4, pp. 183-197.

Murrell, Paul. 2011. R Graphics, 2nd Edition. CRC Press. ISBN 978-1-4398-3176-2.

Nordstrom, D.K., and Wilde, F.D. 2005. Reduction-oxidation potential (electrode method). National Field Manual for the Collection of Water-Quality Data. USGS Series 09-A6.5. pp. 1-22.

Parkhurst, D.L. and Appelo, C.A.J., 1999, User's guide to PHREEQC (version 2)--A computer program for speciation, batch-reaction, one-dimensional transport, and inverse geochemical calculations: U.S. Geological Survey Water-Resources Investigations Report 99-4259, 312 p.

Perry, E.F., 2001. Modelling rock-water interactions in flooded underground coal mines, northern Appalachian basin. Journal of Geochemistry: Exploration, Environment, Analysis. Vol. 1, pp. 61-70.

Perry, E.F. and Hawkins, J.W. 2004. Groundwater flow and quality in a fully flooded underground mine complex. In Proceedings, National Meeting of the American Society of Mining and Reclamation, Morgantown, WV, pp. 1-20. 
R Core Team. 2012. R: A language and environment for statistical computing. R Foundation for Statistical Computing, Vienna, Austria. ISBN 3-900051-07-0, URL http://www.Rproject.org/.

Ruppert, Leslie F., Tewalt, Susan J., Linda J. Bragg, Gerald A. Weisenfluh, Roy S. Sites, Ernest E. Thacker, Bascombe M. Blake, Jr., Philip A. Freeman, David T. Butler, and Leroy C. Bryant. 2001. A Digital Resource Model of the Middle Pennsylvanian Pond Creek Coal Zone, Pottsville Group, Central Appalachian Basin Coal Region. U.S. Geological Survey Professional Paper 1625-C, Chapter G. 92 pp.

Sanchez, E.J. 2008. The acidic mine pit lakes of the Iberian pyrite belt: an approach to their physical limnology and hydrogeochemistry. Journal of Applied Geochemistry. Vol. 23, pp. 1260-1287.

Shramko, A., Palmgren, T., Gallo, D., and Dixit, R. 2009. Analytical characterization of flowback waters in the field. In proceedings: $16^{\text {th }}$ Annual Petroleum and Biofuels Environmental Conference (IPEC), Houston, November 3-5.

Smith, C.P., 1979. Characterization of water quality for deep mine effluents of abandoned pittsburgh and sewickley coal mines near Morgantown, West Virginia. Unpublished M.S. Project Report, Department of Geology and Geography, West Virginia University, Morgantown, WV, 67p.

Stiles, J.M., Donovan, J., Dzombak, D.A., Capo, R.C., and Cook, L. 2004. Geochemical cluster analysis of mine water quality within the Monongahela basin. In Proceedings, National Meeting of the American Society of Mining and Reclamation, Morgantown, WV, pp. 1819-1830.

Stoertz, M.W., Sahu, P., McCament, B., and Bowman J.S. 2004. Hydrology of the abandoned underground Corning coal mine, Perry County, Ohio. In Proceedings, National Meeting of the American Society of Mining and Reclamation, Morgantown, WV, pp. 1831-1853.

Stoner, J.D. 1983. Probable hydrologic effects of subsurface mining. Journal of Ground Water Monitoring Review, Vol. 3, No. 1, pp. 128-137.

Tewalt, Susan J., Leslie F. Ruppert, Linda J. Bragg, Gerald A. Weisenfluh, Ernest E. Thacker, Roy S. Sites, Bascombe M. Blake, Jr., Philip A. Freeman, Leroy C. Bryant, and David T. Butler, 2001. A Digital Resource Model of the Middle Pennsylvanian Fire Clay Coal Zone, Pottsville Group, Central Appalachian Basin Coal Region. U.S. Geological Survey Professional Paper 1625-C, Chapter F. 76 pp. 
Ward, J.H. 1963. Hierarchical grouping to optimize an objective function. Journal of American Statistical Assocation. Vol. 69, pp. 236-244.

West Virginia Geological and Economic Survey. 2007. History of West Virginia mineral industries: Coal. WVGES, Department of Commerce, Morgantown, WV.

Winland, R. L., Traina, S. J., and Bigham, J. M., 1991, Chemical composition of ochreous precipitates from Ohio coal mine drainage: Journal of Environmental Quality, v. 20, p. $452-460$.

Winters, W.R., and Capo, R.C. 2004. Ground water flow parameterization of an Appalachian coal mine complex. Journal of Ground Water, Vol. 42, No. 5, pp. 700-710. 